\title{
Origin and significance of lamination in Lower Cretaceous stromatolites and proposal for a quantitative approach
}

\author{
Pablo Suarez-Gonzalez ${ }^{\mathrm{a}, \mathrm{b}, *}$, I. Emma Quijada ${ }^{\mathrm{a}, \mathrm{b}}, \mathrm{M}$. Isabel Benito ${ }^{\mathrm{a}, \mathrm{b}}$, Ramón Mas ${ }^{\mathrm{a}, \mathrm{b}}$, \\ Raúl Merinero ${ }^{c}$, Robert Riding ${ }^{d}$ \\ a Departamento de Estratigrafia, Universidad Complutense de Madrid, José Antonio No váis 12, 28040 Madrid, Spain \\ b Instita to de Geociencias IGE (CSIC, UCM), José Antonio Novais 12, 28040 Madrid, Spain \\ ' Departamento de Cristalografia y Mineralogia, Universidad Complutense de Madrid, Jo sé Antonio Nováis 12, 28040 Madrid, Spain \\ a Department of Earti and Fianetay Sciences, University of Tennessee, Knoxville, TN 37996, USA
}

Editor: Brian Jones

\section{Keywords:}

Microbialites

Agglutinated stromatolites

Accretion processes

Iamination

Coastal-wetlands

\begin{abstract}
A B S T R A C T
Stromatolite lamination is typically defined as alternation of dark and light laminae. Study of Lower Cretaceous stromatolites from the Leza Fm ( $N$ Spain) supports this statement, but recognises additional complexities in lamination that have implications for interpreting accretion processes. These stromatolites are partial analogues of present-day coarse-grained carbonate stromatolites in the Bahamas and Shark Bay (Australia) that mainly form by trapping and binding carbonate sand. The Leza examples contain both grain-rich and micrite-rich laminae with scarce particles, suggesting that they accreted both by trapping and not trapping grains. Iamination in modem and ancient coarse-grained stromatolites is commonly defined by thin micritic crusts that formed during interruptions in accretion and separate contiguous grainy laminae (repetitive lamination). Leza examples also contain these thin hiatal crusts and locally show repetitive lamination, but their conspicuous macroscopiclamination is defined by thicker alternating grain-rich and micrite-rich laminae (alternating lamination). This indicates that, although hiatuses in accretion occurred, change in accretion process was the main cause of macroscopic lamination. These differences in accretion processes and lamination styles between Leza examples and modern coarse-grained stromatolites may reflect differences in their environmental settings. Modern examples occur in shallow marine tidal environments, whereas Leza Fm coarse-grained stromatolites developed in tideinfluenced water-bodies in coastal-wetlands that experienced fluctuations in water salinity and hydrochemistry. Analysis of lamina-thickness in these Cretaceous stromatolites and similar published examples provides a quantitative approach to the processes that underlie stromatolite lamination.
\end{abstract}

\section{Introduction}

Lamination is a defining feature of the microbial sediments that Kalkowsky (1908) named stromatolites. Clearly visible in examples as old as 3.5 billion years (Hofmann et al., 1999; Allwood et al., 2006), lamination distinguishes stromatolites from other microbial carbonates such as dendrolites, thrombolites and leiolites (Riding, 2011). The shape, continuity, and stacking of aminae are important in stromatolite description and classification (Hofmann, 1969, 1973; Monty, 1976; Semikhatov et al., 1979; Grey, 1989; Grotzinger and Knoll, 1999), including the definition of stromatolite morphotypes (Maslov, 1960; Vologdin, 1962; Walter, 1972; Semikhatov and Raaben, 2000). Stromatolite lamination has been examined for periodicity (e.g. Jones, 1981; Takashima and Kano, 2008; Petryshyn et al., 2012) and pattern of

* Corresponding author at: Departamento de Estratigrafia, Universidad Complutense de Madrid, José Antonio Nováis 12, 28040 Madrid, Spain. Tel.: + 34 913944783; fax: + 34 913944808.

E-mail address: pablosuarez@geo.ucm.es (P. Suarez-Gonzalez). arrangement (e.g. Zhang et al., 1993; Batchelor et al., 2000; Dupraz et al., 2006; Wagstaff and Corsetti, 2010; Petryshyn and Corsetti, 2011; Mata et al., 2012), but quantitative analyses of stromatolite lamina thickness are not common (e.g., Komar et al., 1965; Bertrand-Sarfati, 1972; Petryshyn et al., 2012).

Microbial mat communities can develop well-layered distributions in response to vertical physicochemical gradients (e.g., Schulz, 1936; Javor and Castenholz, 1981; Nicholson et al., 1987), but this biological stratification does not appear to be the principal precursor to the lamination that is preserved in lithified mats (Golubic, 1991). Early studies of present-day stromatolites and other laminated microbial deposits, such as oncoids, related layering to seasonal variations in growth and calcification (Roddy, 1915) and to the size of trapped grains and altemation of sediment-rich and organic-rich layers (Black, 1933). Subsequent work has supported and extended this view, and it is now widely accepted that primary lamination reflects episodic, in some cases iterative, changes in accretion variously related to variations in microbial growth and calcification, inorganic precipitation, and grain trapping (e.g., Cloud, 1942; Ginsburg and Lowenstam, 1958; Logan, 1961; Hofmann, 1973, 
1977; Doemel and Brock, 1974; Monty, 1976; Park, 1976; Semikhatov et al., 1979; Jones, 1981; Braga et al., 1995; Grotzinger and Knoll, 1999; Reid et al., 2000; Riding, 2000, 2011; Seong-Joo et al., 2000; Storrie-Lombardi and Awramik, 2006; Planavsky and Grey, 2008; Dupraz et al., 2009; Wagstaff and Corsetti, 2010; Petryshyn and Corsetti, 2011; Mata et al., 2012; Petryshyn et al., 2012).

A goal of stromatolite research is to be able to confidently discriminate between these accretion processes in order to interpret the origin of lamination. In ancient examples this eff ort is often hindered by poor preservation, but there is an additional complication in that lamination can also be generated by hiatuses, as observed in modern coarsegrained carbonate stromatolites (sensu Awramik and Riding, 1988) from Shark Bay and the Bahamas (Monty, 1976; Reid and Browne, 1991; Reid et al., 1995, 2000, 2003). This key distinction was recognised by Monty (1976) in a wide-ranging study of present-day stromatolites. He distinguished two main lamination styles: alternating lamination, produced by superposition of laminae of diff ering texture, and repetitive lamination, where hiatuses, marked by thin dark horizons, separate laminae of similar texture (Monty, 1976).

In this study, we examine well preserved Cretaceous stromatolites from the Leza Formation (Cameros Basin, N Spain) that exhibit both repetitive and alternating lamination. These examples mainly consist of ooids, peloids and bioclasts, together with micritic laminae. Their fabrics resemble those of well-known present-day coarse-grained carbonate stromatolites (Logan, 1961; Golubic and Hofmann, 1976; Monty, 1976; Dravis, 1983; Dill et al., 1986; Awramik and Riding, 1988; Reid and Browne, 1991; Riding et al., 1991a; Reid et al., 1995, 2000, 2003; Macintyre et al., 1996, 2000; Feldmann and McKenzie, 1998; Planavsky and Ginsburg, 2009; Dupraz et al., 2011; Jahnert and Collins, 2011, 2012, 2013). The Leza Fm contains some of the earliest known examples of coarse-grained carbonate stromatolites, and these are unusual in exhibiting both of the lamination styles defined by Monty (1976). Co-occurrence of these contrasting lamination styles sheds light on their processes of formation. They reveal how lamination can be produced by either hiatuses in accretion or by changes in the process of accretion (i.e. rapping and binding of grains vs. in-situ calcification of microbial mats without significant grains), and how these in turn reflect environmental controls. It also draws attention to distinct differences in macroscopic appearance: repetitive lamination is much less conspicuous, and the prominent lamination that characterises Leza coarse-grained stromatolites in field occurrences and hand-specimens is dominantly alternating lamination. We develop a metrical methodology to quantitatively describe and distinguish these lamination styles, which could be applied in other studies of ancient and present-day stromatolites.

\section{Ceologic setting}

The stromatolites studied here belong to the Lower Cretaceous Leza Formation in the Cameros Basin, the northemmost basin of the Mesozoic Iberian Rift System (Mas et al., 2002b) (Fig. 1). The Cameros Basin developed during Tithonian (latest Jurassic) to Albian (late Early Cretaceous) times, and records up to $6000 \mathrm{~m}$ of continental and transitional sediments (Alonso and Mas, 1993; Quijada et al., 2010, 2013a, 2013b; Suarez-Gonzalez et al., 2010, 2013, in press). The upper Barremianlower Aptian Leza Fm was deposited in a series of small fault-bounded depressions on the northern margin of the basin (Fig. 2) (SuarezGonzalez et al., 2013, in press). It consists of up to $280 \mathrm{~m}$ of carbonates with variable siliciclastic input (Suarez-Gonzalez et al., 2010, 2013, in press). The depositional seting of the Leza Fm has been interpreted as a system of coastal-wetlands formed by broad and relatively vegetated

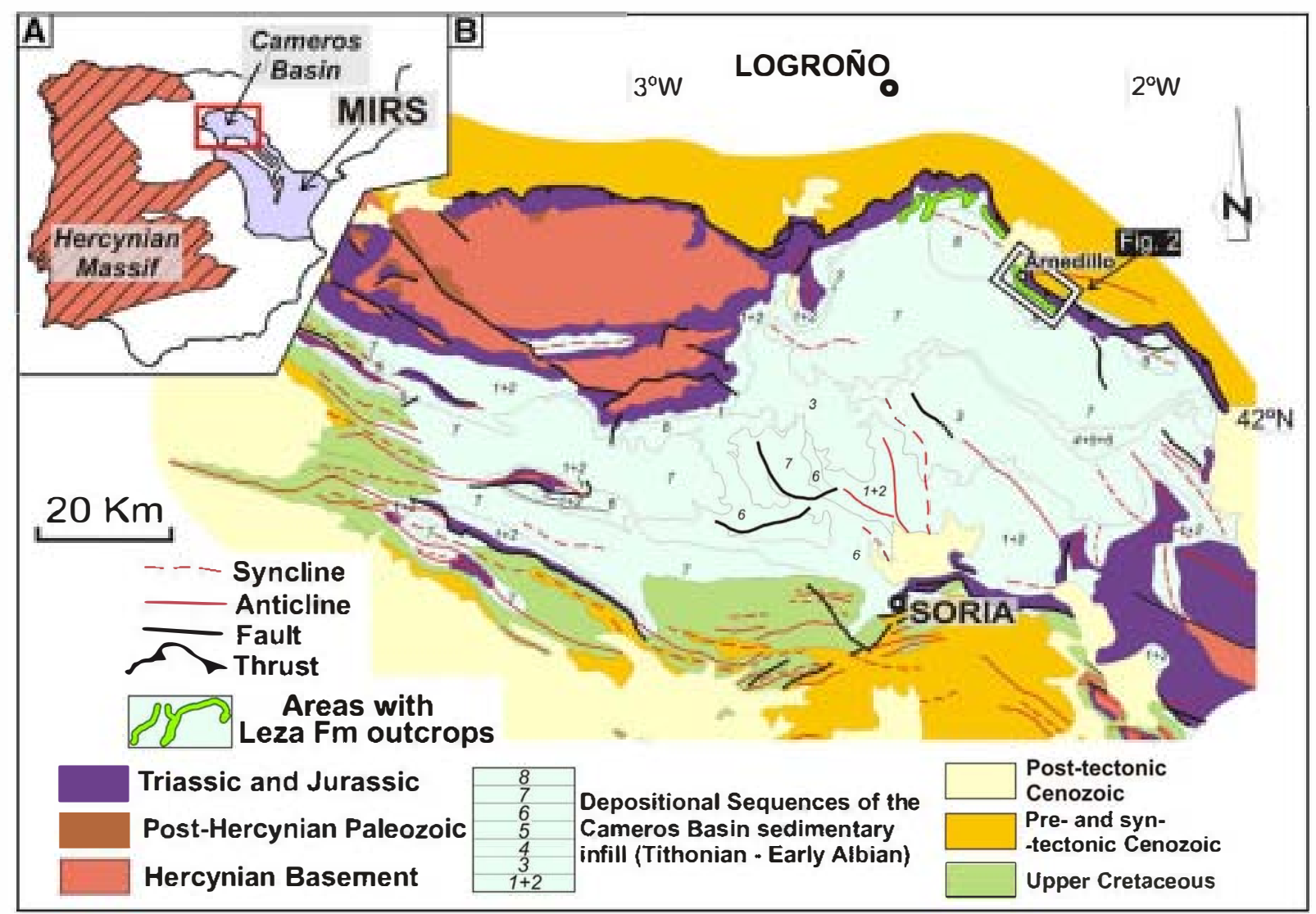

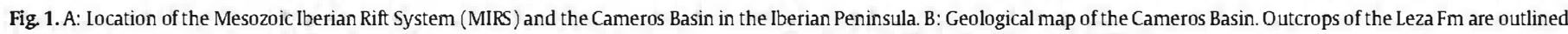
in green and a rectangle shows the location of the eastem outcrops of the Leza Fm, mapped in Fig. 2. Modified after Mas et al (2002a). 


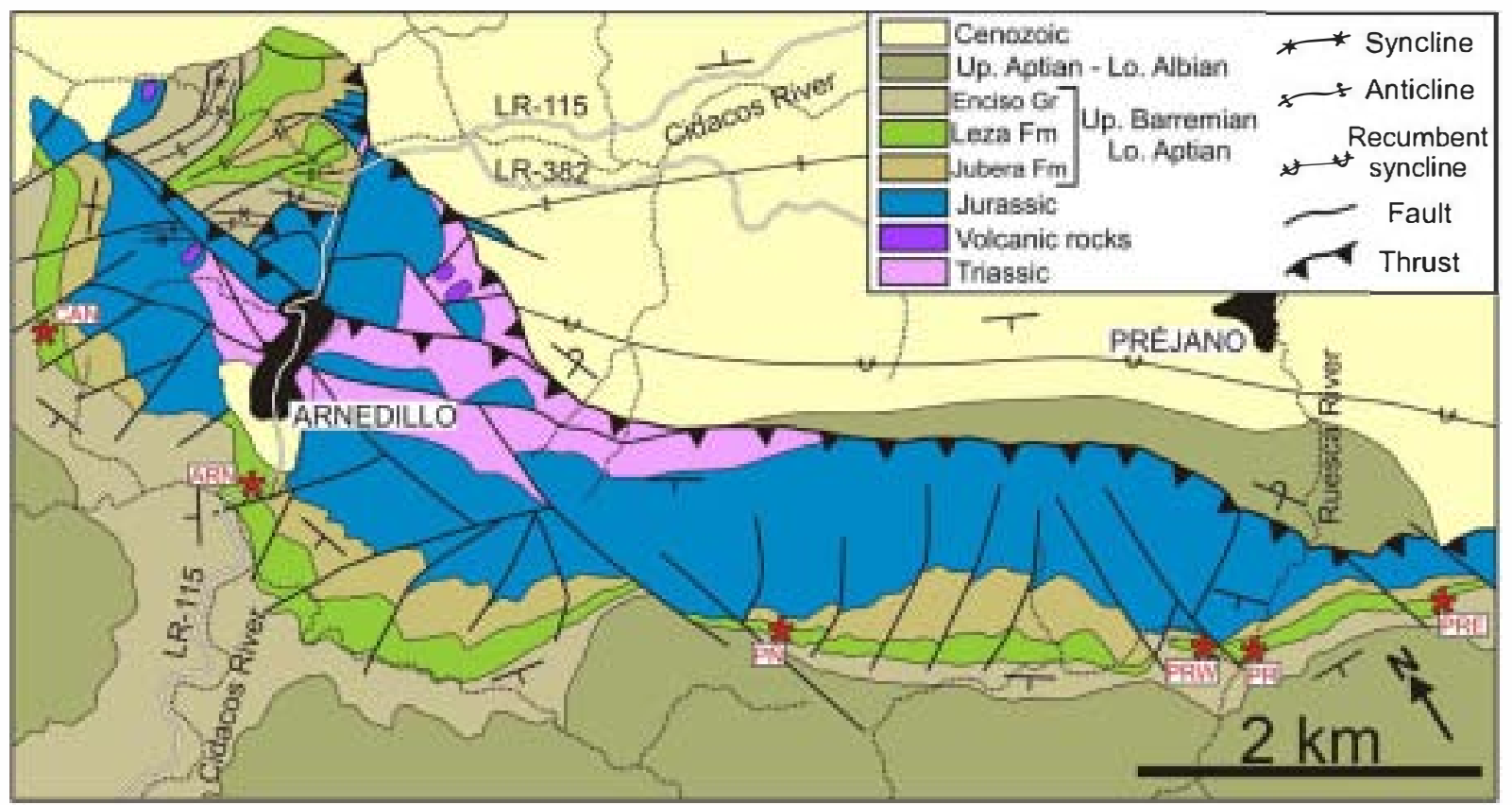

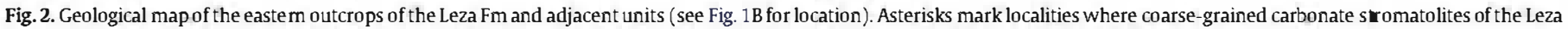
Fm have been observed and sampled. CAN: Canteras. ARN: Arnedillo. PÑ: Peñalmonte. PRW: West Préjano. PR: Préjano. PRE: East Préjano.

plains with shallow water-bodies, which had influence of both freshwater and seawater (Suarez-Gonzalez et al., 2013, in press). Leza coarsegrained stromatolites have only been observed in the eastern area of this system (Figs. 1B, 2), where four facies associations can be distinguished (Fig. 3; Suarez-Gonzalez et al., 2013): clastic facies, interpreted as alluvial sandstones and conglomerates, laterally related to the water-bodies of the coastal-wetlands; black limestones facies, deposited in water-bodies influenced by freshwater and/or seawater, as shown by the presence of both continental (charophytes, terrestrial vertebrates) and marine (dasyclad algae) fossils; oolite-stromatolite facies, deposited in tide-influenced water-bodies dominated by seawater (with ostracodes and miliolid foraminifers); evaporite-dolomite facies, deposited in relatively restricted water-bodies dominated by seawater, with high salinity and probably local tidal influence.

Leza coarse-grained stromatolites occur in the oolite-stromatolite facies association, which mainly consists of cross-bedded grainstones (Fig. 4) with flaser, wavy, and lenticular bedding (Suarez-Gonzalez et al., in press). Stromatolites pass laterally into, and are interbedded with, the grainstones (Fig. 4). These grainstones are medium-coarse grained carbonate sand (mean $\sim 0.5 \mathrm{~mm}$ ) (Fig. 4B, D) composed of ooids, peloids, intraclasts and bioclasts (ostracodes, miliolid foraminifers). These fossils are abundant, but show very low diversity. Ooid nuclei are generally peloids, intraclasts and quartz grains, but can also be bioclasts (ostracodes, dasyclads, charophytes). Flat pebble breccias formed by micritic intraclasts and stromatolite fragments are common in the oolite-stromatolite facies, closely associated with the stromatolites (Fig. 4C). This facies association is interpreted as tide-influenced waterbodies seaward of the Leza coastal-wetlands (Suarez-Gonzalez et al., 2013, in press). Given the general paralic setting, freshwater input is a likely cause of the low diversity of marine fauna (Suarez-Gonzalez et al., in press). However, local pseudomorphs after evaporites (see Sections 4.2 .5 and 5.1.4, below) indicate that hypersaline conditions also occurred.

\section{Methods}

In the eastern outcrops of the Leza Fm (Figs. 1B, 2), 26 horizons of coarse-grained stromatolites were observed along 6 measured stratigraphic sections (Fig. 2). A total of 29 stromatolite samples were examined in polished hand specimens and in corresponding thinsections prepared perpendicular to the lamination, that were partially stained with Alizarin Red S and potassium ferricyanide (Dickson, 1966), to distinguish calcite and dolomite. Thin-sections were compared with their corresponding hand specimens in order to relate the macroscopic lamination to accretion processes, interpreted by petrographic study.

Quantitative analysis of lamination was based on lamina thickness, using 14 representative thin-sections of Leza coarse-grained stromatolites. Laminae were characterised by microfabric under the microscope (see Section 4.2 , below), and 12 to 15 lamina-thickness values were measured in each thin-section using an ocular micrometer. A total of 192 lamina measurements were obtained. This metric approach was inspired by methods applied to Proterozoic stromatolites by Komar et al. (1965), Bertrand-Sarfati (1972), Walter (1972), and Preiss (1973), in which the relative thicknesses of dark and light laminae were used to characterise different stromatolite taxa (see Sections 4.4 and 5.3, below). We also applied this methodology used in Leza coarse-grained stromatolites to published examples of coarse-grained stromatolites. Data management and analysis were performed using the free software R 2.15.2 (R Development Core Team, 2012).

\section{Stromatolite description}

\subsection{Macroscopic features}

Leza coarse-grained stromatolites are interbedded with and pass laterally into ooid grainstones (Fig. 4), forming beds up to $40 \mathrm{~cm}$ thick that extend laterally for up to $100 \mathrm{~m}$. Their morphologies range from laterally linked domes $70 \mathrm{~cm}$ across and $40 \mathrm{~cm}$ high (Fig. 4A) to stratiform deposits with elevated areas (Fig. 4C, E). They show distinct macroscopic lamination (Fig. 4C, D, E) formed by darker and lighter laminae, $0.5-4 \mathrm{~mm}$ thick. The laminae have gradational to sharp contacts with generally smooth surfaces and a high degree of inheritance (Fig. 5A).

\subsection{Microscopic features}

When observed under the microscope, laminae of Leza coarsegrained stromatolites contain a variety of textural components, creating 


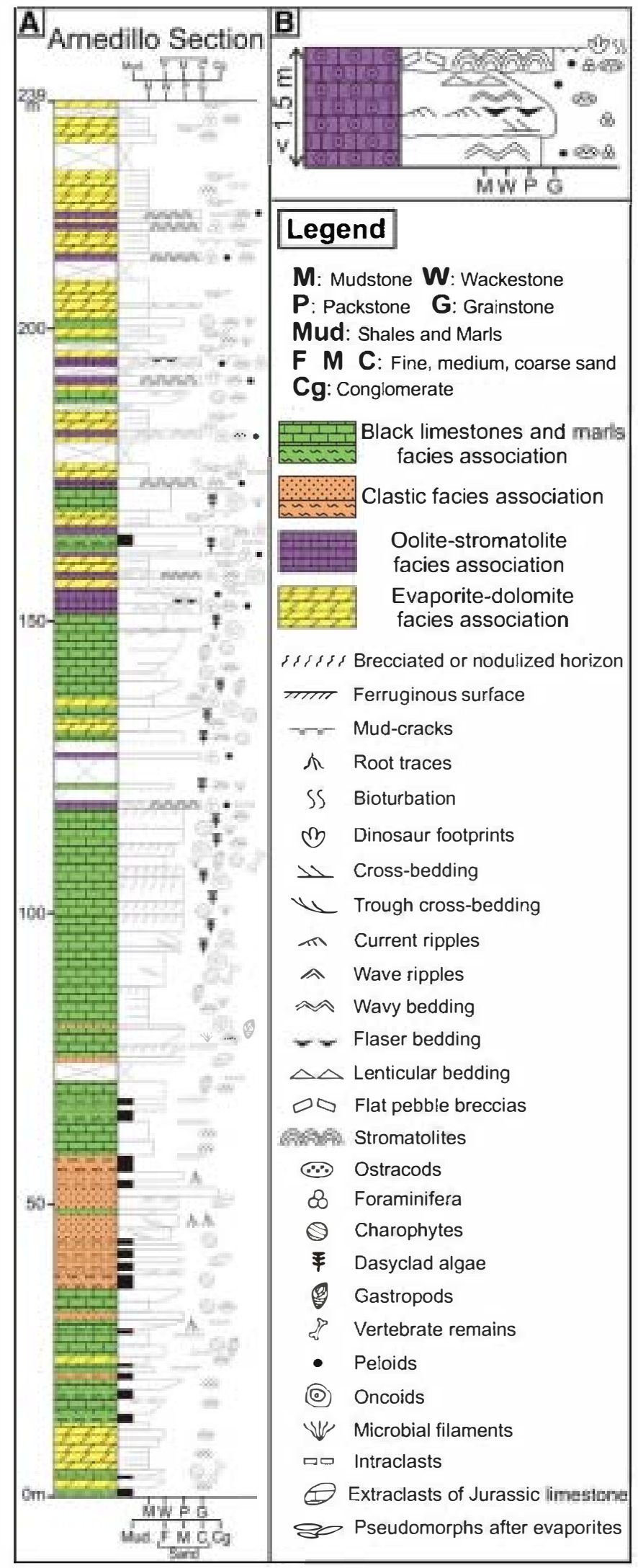

Fig. 3. A: Simplified log of the Arnedillo section, which is representative of the facies and their vertical distribution in the eastern outcrops of the Leza Fm. B: Facies sequence of the oolite-stromatolite facies association, which contains the stromatolites studied here. diff erent microfabrics (Fig. 5). The mineralogy is generally calcite, but partial dolomitisation of ooids and micritic matrix is observed. In addition to ooids and other sand-size carbonate grains (peloids, intraclasts and bioclasts), which are common (Figs. 5-12), micrite is also present, together with rare calcified filaments and pseudomorphs after evaporites. Various combinations and proportions of these components produce the variety of laminae in Leza coarse-grained stromatolites.

\subsubsection{Grainy laminae}

Grainy laminae are formed almost exclusively by medium-coarse grained carbonate sand (Figs. 5B, 6): ooids (typically superficial ooids, sensu Carozzi, 1957), peloids, bioclasts (ostracodes, foraminifers), micritic intraclasts and rare quartz grains (Figs. 5B, 6). Identical grain types occur in the oolitic grainstones surrounding the stromatolites. Ooid nuclei are generally peloids and micritic intraclasts, and less commonly quartz grains and fragments of ostracodes, dasyclads and charophytes. Composite ooids occur occasionally (Fig. 6B). Grain-size in the stromatolites ranges $100-800 \mu \mathrm{m}$ (mean $\sim 350 \mu \mathrm{m}$ ), and is finer than in the surrounding sediment (mean $\sim 500 \mu \mathrm{m})$. Intergranular space is filled by sparite cement and/or clotted-peloidal micrite (Figs. 5B, 6). Laminae are up to $3 \mathrm{~mm}$ thick and generally smooth, forming horizontal to steeply dipping (up to $90^{\circ}$ ) layers on the tops and flanks of stromatolite domes, respectively. Macroscopically, they appear generally continuous, but often pinch or disappear laterally in thin section.

\subsubsection{Micritic laminae}

Micritic laminae are common in Leza coarse-grained stromatolites (Figs. 5C, 6B, 7). They are mainly formed by clotted and clottedpeloidal fabrics, and less commonly dense fabric, and contain very few scattered carbonate grains (Figs. 5C, 6B, 7A). Clotted fabric is composed of irregular micrite clots, $30-200 \mu \mathrm{m}$ across, separated by irregularly shaped fenestrae filled with microsparite or sparite cement (Fig. 7A). Clotted-peloidal fabric is composed of peloids, $20-80 \mu \mathrm{m}$ across, and scarcer micrite clots (Fig. 5C). Peloids are surrounded by microsparite cement and are typically concentrated in areas $0.1-1.5 \mathrm{~mm}$ across, which may be separated by irregularly shaped fenestrae (Figs. 5C, 6B). Dense micrite is less common (Fig. 7C). Micritic laminae of Leza coarse-grained stromatolites are generally thinner $(<2 \mathrm{~mm})$ and more irregular than grainy laminae, locally even developing micro-domes (Fig. 7A). Lateral pinching is common. As in the case of grainy laminae, micritic laminae occur in both flat and domal areas of the stromatolites, with varied dip angles.

\subsubsection{Mixed laminae}

Grainy and micritic laminae form a series ranging from purely grainy to wholly micritic, but with most laminae of the Leza coarse-grained stromatolites being mixtures with diff erent proportions of both carbonate grains and micrite, here termed mixed laminae (Figs. 8, 9). When observed in detail, subtle and gradual changes between micritic and grainy microfabrics can be observed in some mixed laminae (Fig. 9A). Nonetheless, it remains useful to distinguish grain-dominated mixed laminae (with abundant subordinate intergranular micrite, Figs. 7B, 8) and micrite-dominated mixed laminae (micritic laminae with locally abundant grains, typically concentrated in isolated pockets, Figs. 7C, 8). Very occasionally, mixed laminae also contain poorly preserved calcified filaments (Fig. 7B, C). These lack a well-defined calcified sheath and instead occur as elongated clusters of clotted-peloidal micrite (Fig. 7B) or thin micritic rims perpendicular to lamination (Fig. 7C). Mixed laminae are smooth, laterally quite continuous, and generally 1-4 mm thick; but laminae up to $6 \mathrm{~mm}$ are also present. Mixed laminae exhibit varied dip angles, both in flat and flank areas of domes.

\subsubsection{Thin micritic crusts}

Dark thin micritic crusts, $25-500 \mu \mathrm{m}$ in thickness (average $140 \mu \mathrm{m}$ ), overlie laminae of differing microfabric composition. They typically 

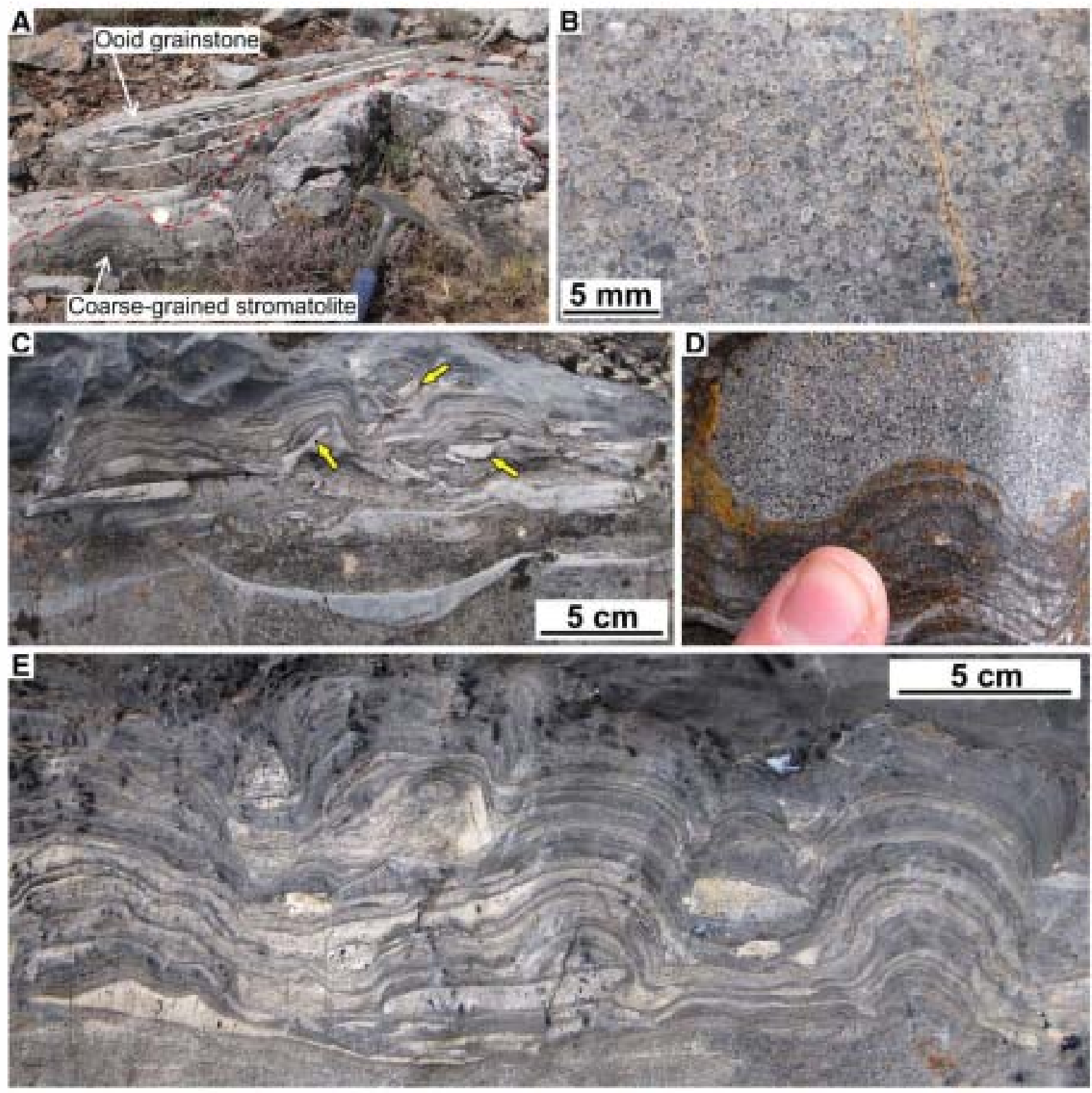

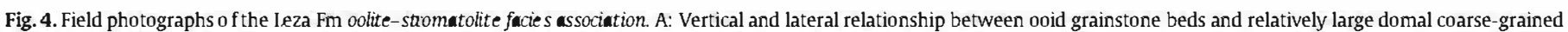

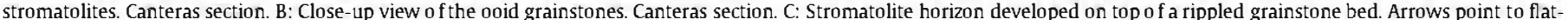

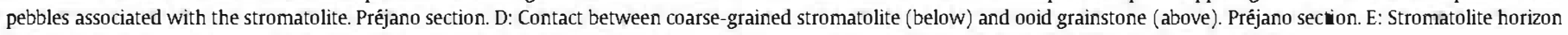
showing laterally-linked domes and stratiform morphologies displaying the characteristic lamination of Ieza coarse-grained stromatolites. Prêjano section.

overlie grainy laminae or grain-dominated mixed laminae, and less commonly micritic laminae or micrite-dominated mixed laminae (Figs. 9, 10, 11). They are composed of micrite that is either dense, clotted or clotted-peloidal. They differ from micritic laminae in not forming thick laminae, and in only occurring superposed on other, and thicker, laminae. They characteristically show diff use and irregular lower surfaces and sharp upper surfaces (Figs. 9, 10,11). Although thin micritic crusts are common in Leza coarse-grained stromatolites, they are macroscopically inconspicuous and are only clearly noticeable under the microscope (compare Fig. 5A with Figs. 8, 9A). Thin micritic crusts are varied and complex: less developed crusts are typically very thin $(\sim 100 \mu \mathrm{m})$ and form a thin micritic film gradually passing downwards into clotted-peloidal micrite (Figs. 9D, 10A). More developed crusts are generally thicker $(\sim 500 \mu \mathrm{m})$ and involve the micritisation and fusion of carbonate grains underlying the crust (Figs. 9D, 10B, 11). Small crystals of pyrite, $<20 \mu \mathrm{m}$, can form thin levels, commonly near the upper surface of the crust (Figs. 7C, 9E).

\subsubsection{Evaporite laminae}

These are very minor components of the Leza coarse-grained stromatolites and have only been observed in four samples. They are formed by contiguous aggregates of calcite, dolomite and quartz pseudomorphs after sulphates (Fig. 12). Aggregates are up to $6 \mathrm{~mm}$ across, they deform the adjacent laminae (Fig. 12A), and incorporate primary components such as ooids and micrite clots (Fig. 12B). Individual pseudomorphs are $0.2-1.5 \mathrm{~mm}$ long (Fig. 12) and display lenticular and tabular habits (Fig. 12B), characteristic of gypsum and anhydrite, respectively (e.g., Warren, 2006 and references therein).

\subsection{Lamination}

In outcrop and hand-specimens, Leza coarse-grained stromatolites are well-laminated (Fig. 3). To relate this characteristic lamination to the stromatolite microfabrics, we compared polished hand specimens with thin-sections of the same samples (Figs. 5, 8, 9). In addition to 


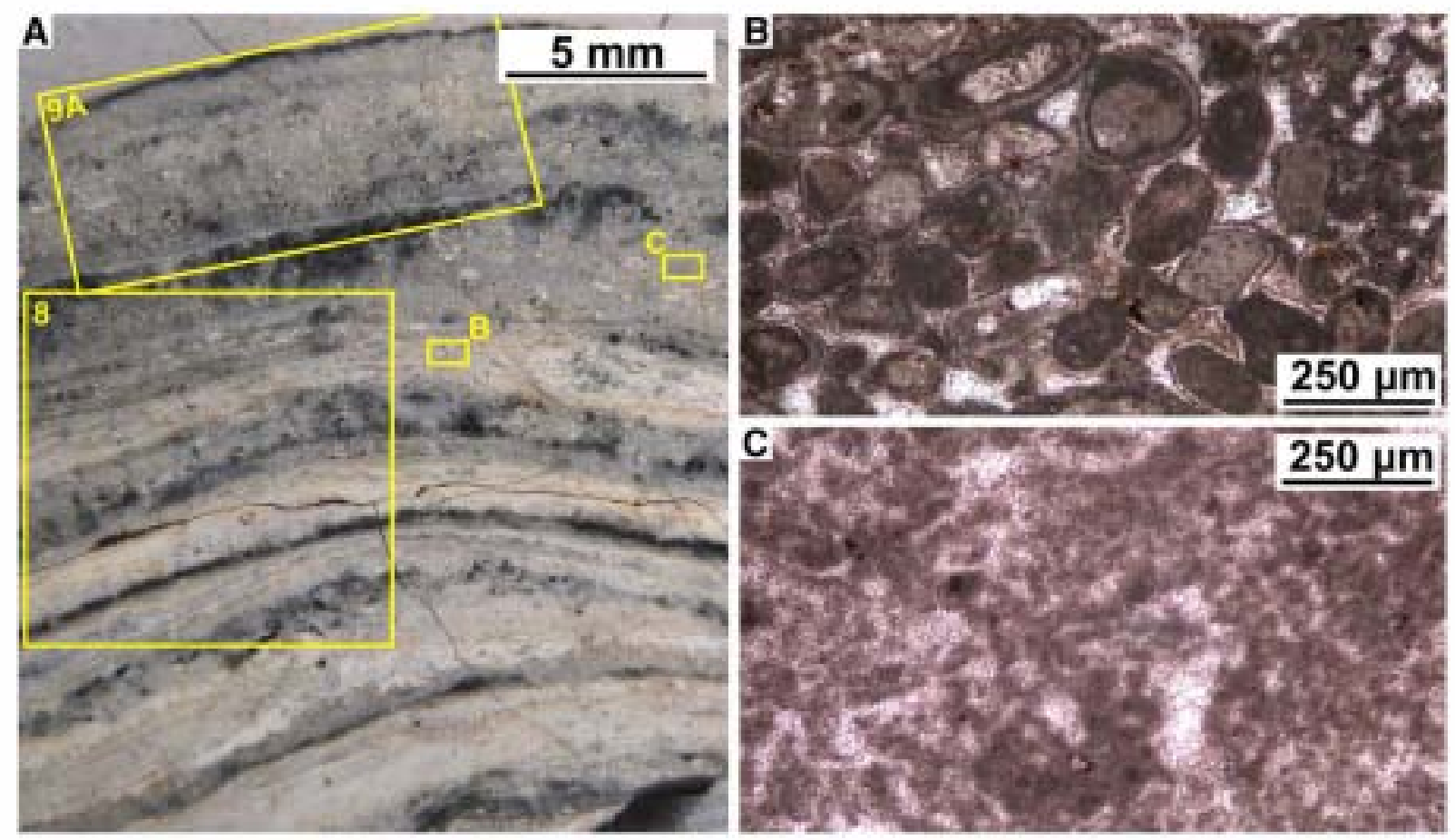

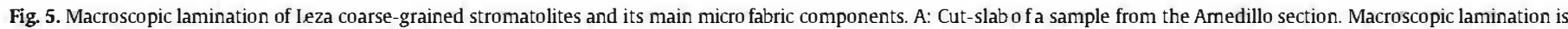

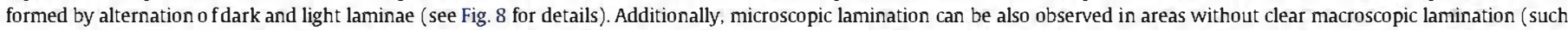

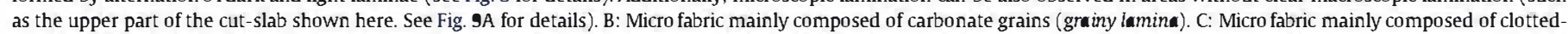
peloidal micrite (micritic lamina).

the well-defined macroscopic lamination, a microscopic lamination is also observed that is produced by the thin micritic crusts.

\subsubsection{Macroscopic lamination}

Conspicuous macroscopic lamination is produced by alternation of darker and lighter layers typically $0.5-4 \mathrm{~mm}$ thick (Figs. 4E, 5A, 8A). When observed in detail, this shading is more complex than just dark and light. Under the microscope, the conspicuous colour contrast between laminae that defines macroscopic lamination can be related to changes on the microfabric of the laminae (i.e., changes in proportions of grains, micrite and cement; see Fig. 8). These changes are generally an alternation between grain-rich and micrite-rich laminae, even in samples dominated by successive mixed laminae (Figs. 5, 8). This style of stromatolite lamination, formed by superposition of laminae with contrasting microfabric composition, corresponds with that defined as alternating lamination by Monty (1976). Under the microscope, the contact between successive macroscopic laminae is generally abrupt and sharp. It can be marked by a thin micritic crust (Fig. 8), although transitional contacts are also observed (Fig. 6B). Erosive contacts occur rarely (Fig. 10B), and are typically associated with the top surface of thin micritic crusts.

\subsubsection{Microscopic lamination}

When observed under the microscope, some areas of stromatolite thin-sections show a fine-scale lamination that is not readily observed in hand specimen, and which is formed by contiguous laminae of similar microfabric composition that are separated by thin micritic crusts (Figs. 9A, C, D, 10A, 11). Thin micritic crusts can occur at the contact between successive laminae of diff ering microfabric (Figs. 8B, 9B), but they are most conspicuous when they separate similar laminae. In this case they create microscopically distinct lamination. This is due to their dense and dark appearance, which contrasts with the adjacent laminae (typically grainy laminae or grain-dominated mixed laminae, but also micrite-dominated mixed laminae), that are more cement-rich and therefore lighter in appearance (Figs. 9, 10,11). This style of stromatolite lamination, formed by superposition of laminae of similar microfabric
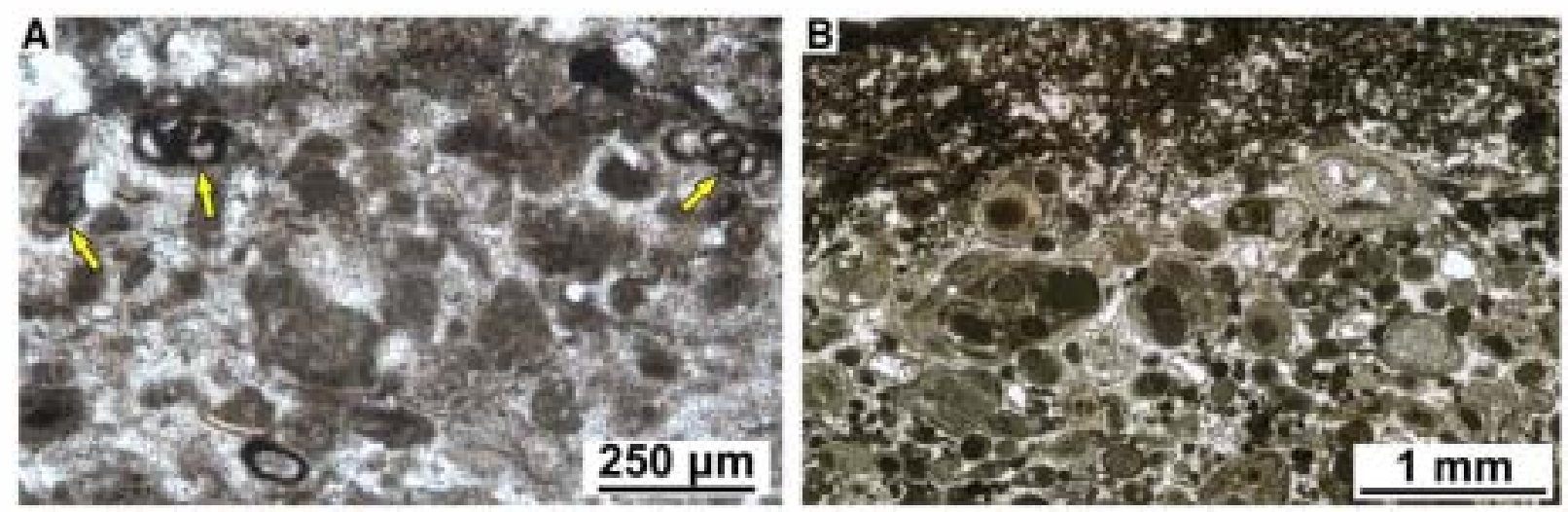

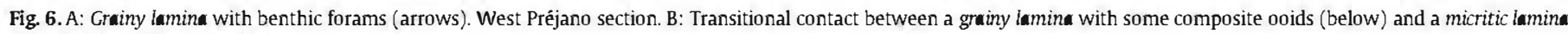
(above). West Préjano section. 

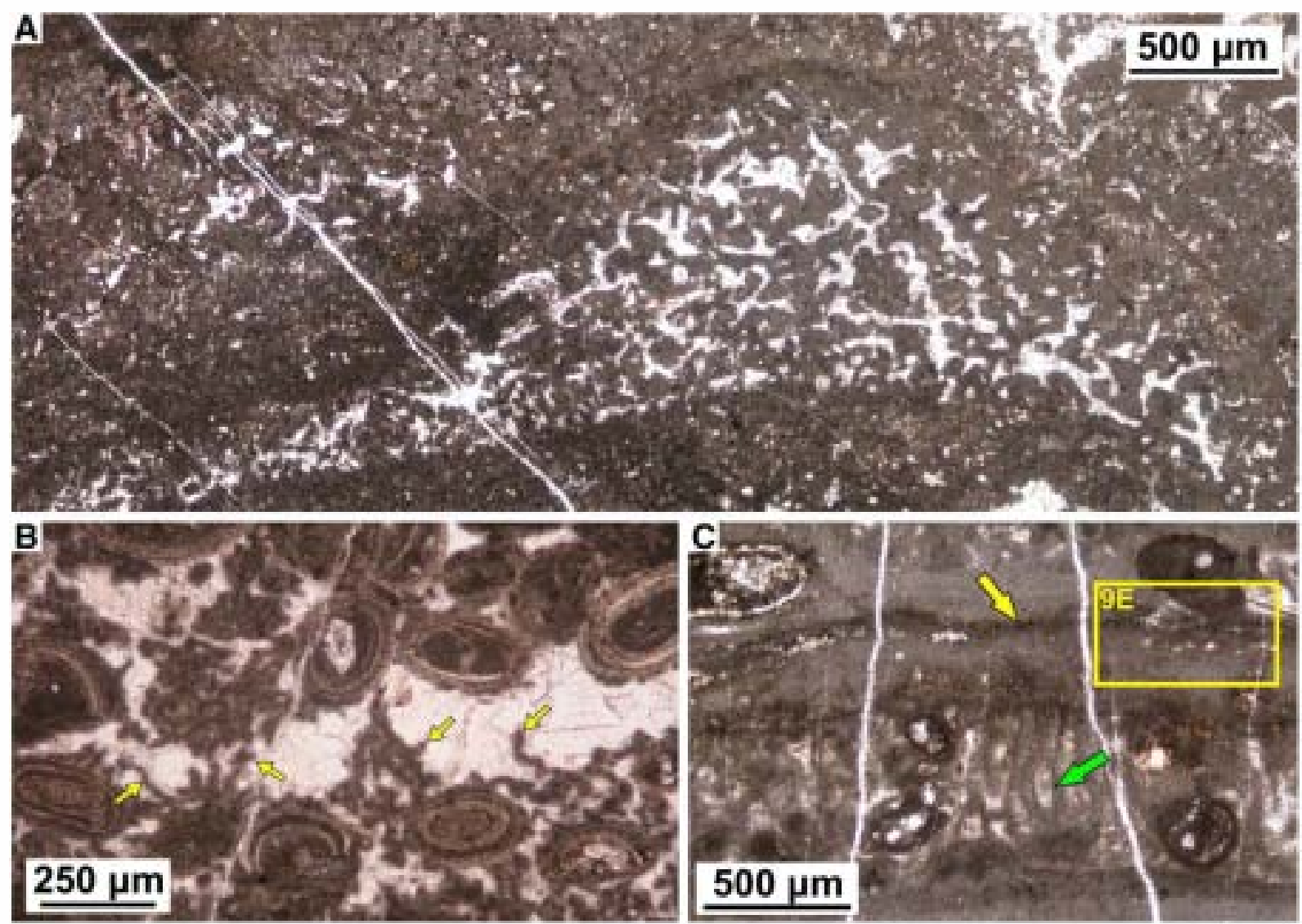

Fig. 7. A: Micritic laminae composed of clotted micrite forming a millimetric domal shape. Arnedillo section. B: Calcified microbial filaments preserved as clusters of sinuous elongate clotted-peloidal micrite in a grain-dominated mixed lamina. Canteras section. C: Subvertical calcified microbial filaments (green arrow) preserved as micritic rims in the micrite dominated mixed lamin of the lower half of the image. This lamina is topped by a thin micritic crust which includes a level of small pyrite crystals (yellow arrow). West Préjano section.

composition separated by thin dark horizons, corresponds to repetitive lamination defined by Monty (1976). He recognised repetitive lamination in present-day coarse-grained carbonate stromatolites from Shark
Bay as thin lithified micritic layers ( $\sim 500 \mu \mathrm{m}$ thick) that mark discontinuities in loosely packed unlithified grainy laminae, up to $3 \mathrm{~mm}$ thick The same lamination style was subsequently recognised and studied
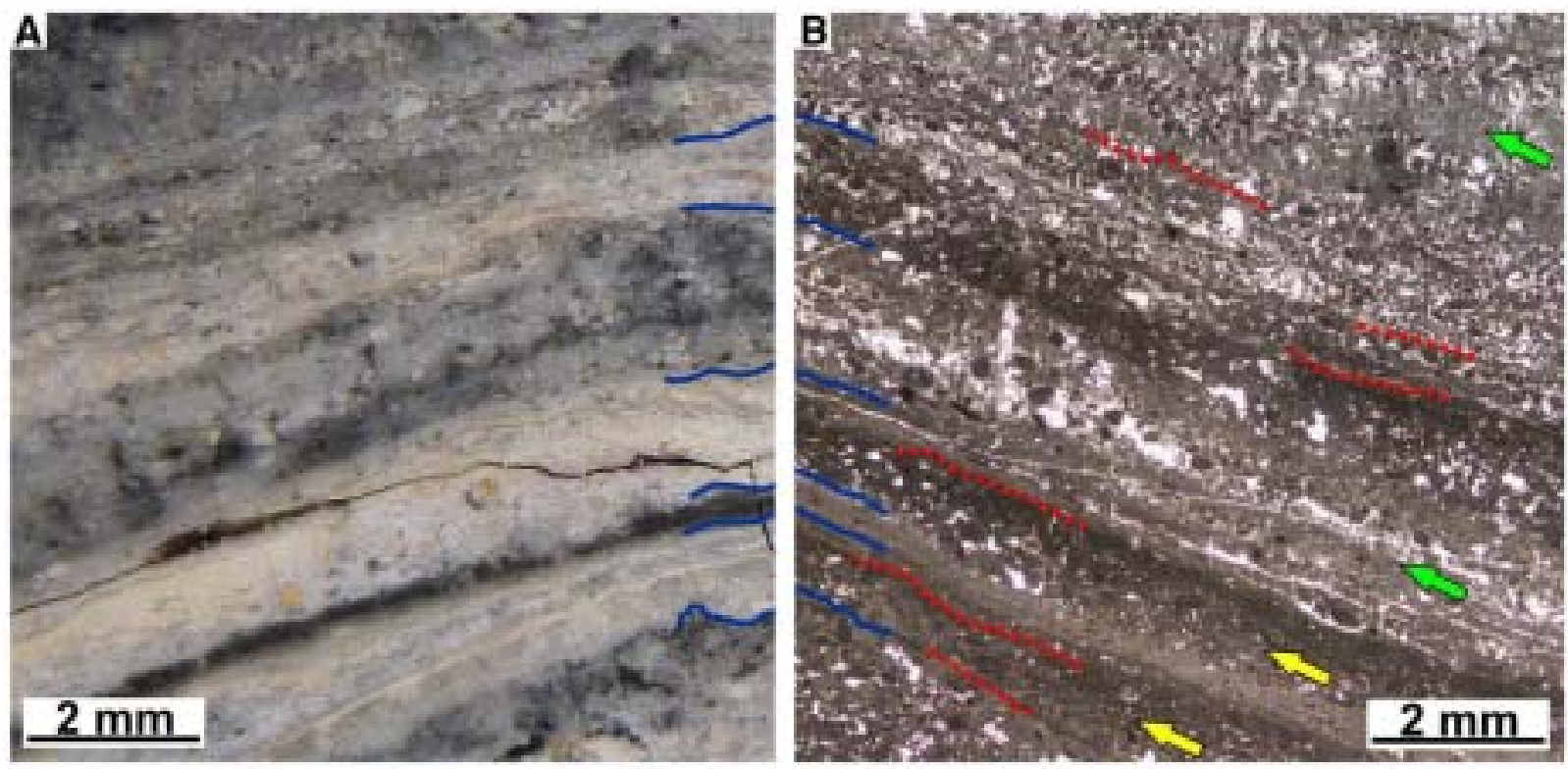

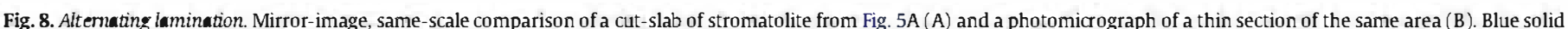

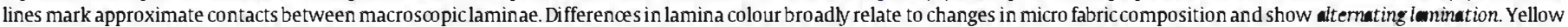

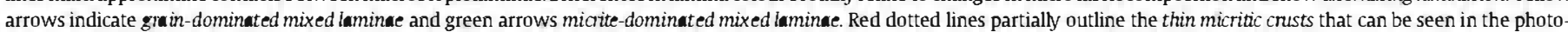
micrograph (B). Note that these are generally macroscopically inconspicuous and only the thickest ones can be seen in the magnified cut-slab (A). Arnedillo section. 


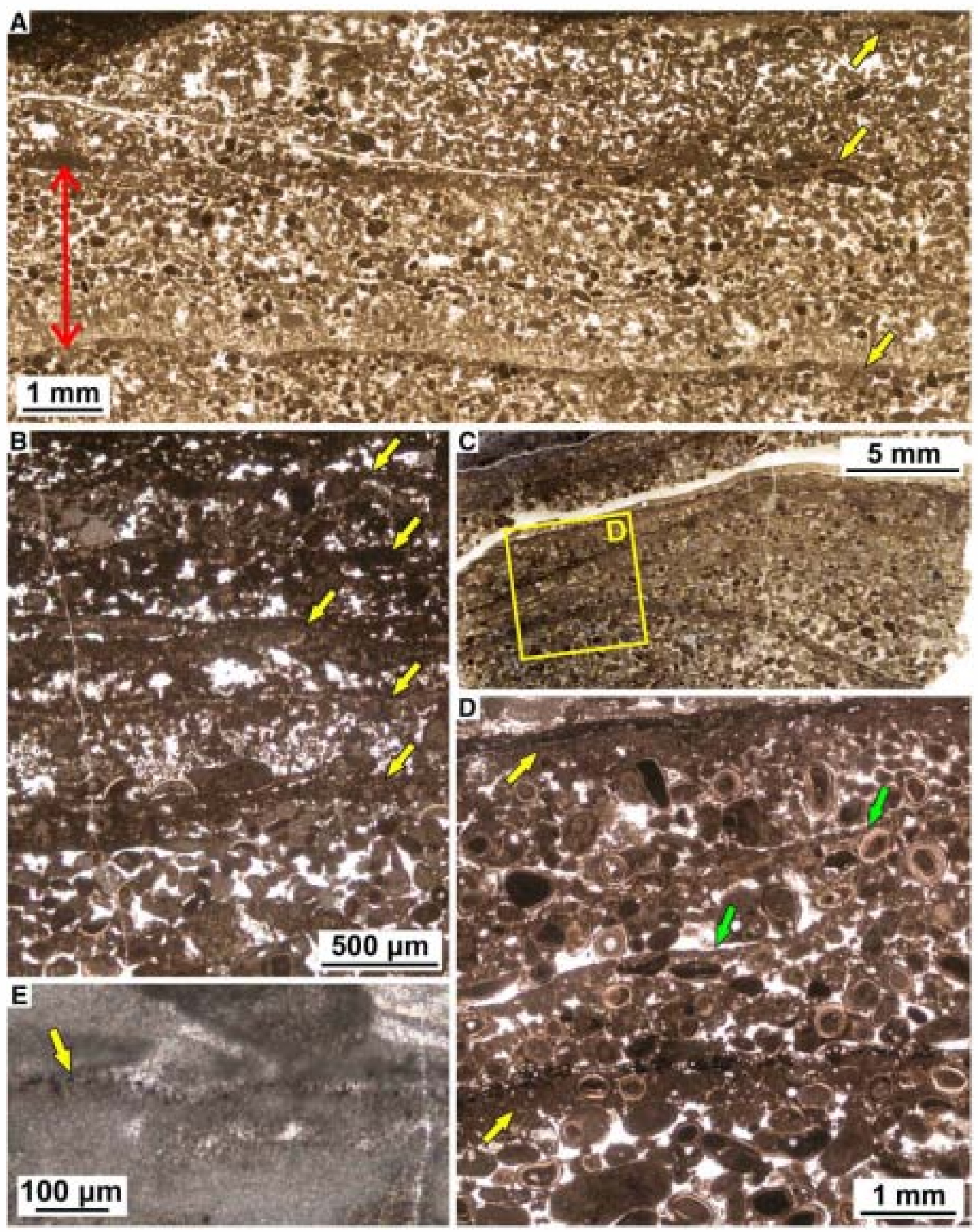

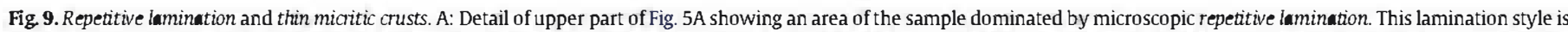

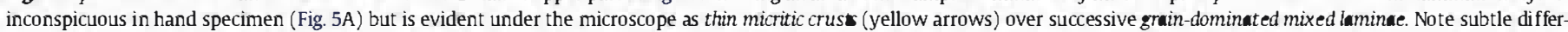

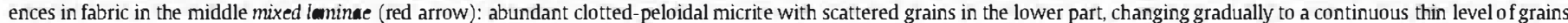

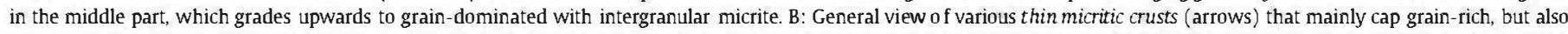

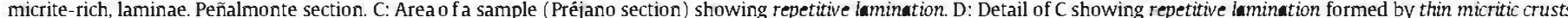

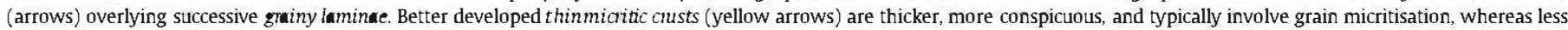

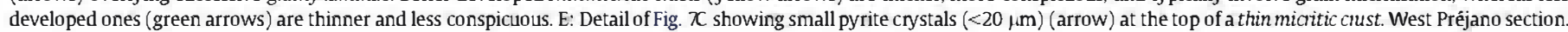

in Bahamian coarse-grained stromatolites (Reid and Browne, 1991; Reid et al., 1995, 2000; Macintyre et al., 1996, 2000; Feldmann, 1997; Feldmann and McKenzie, 1998; Visscher et al., 1998, 2000).
Although lamination in Leza coarse-grained stromatolites is in general dominated by alternating lamination (Figs. 4E, 5, 8), repetitive lamination dominates some areas of the samples (see upper part of 

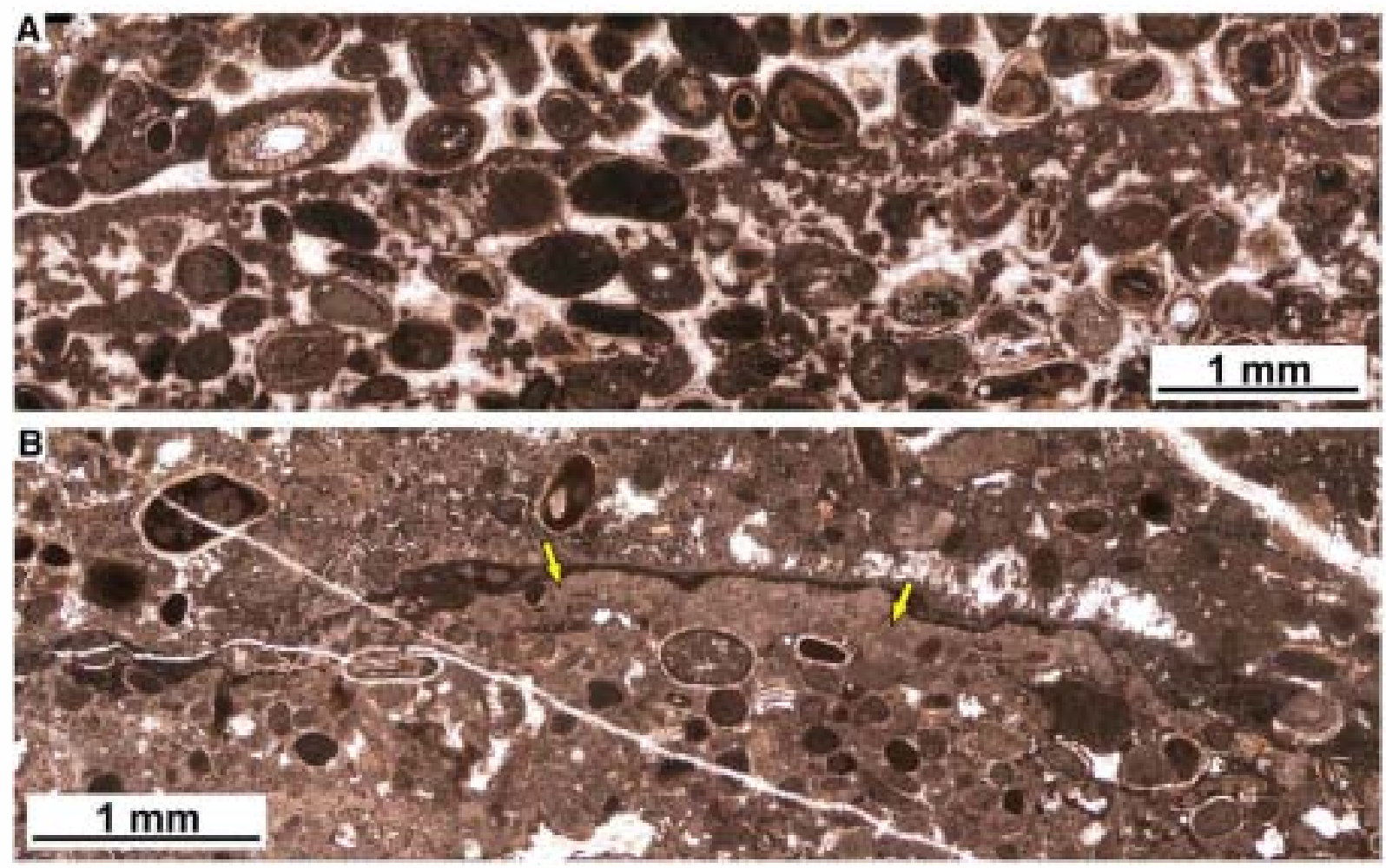

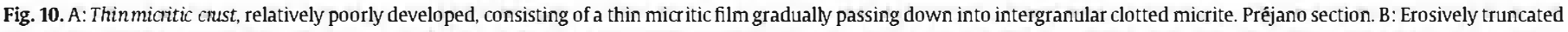

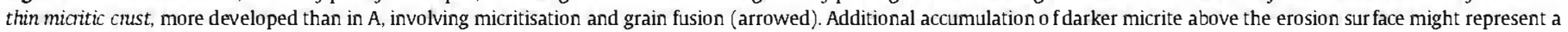
superposed thin micritic crust. Arnedillo section.

Fig. SA). In addition, thin micritic crusts also occur locally within some of the thicker laminae that define the macroscopic alternating lamination, forming a subordinate smaller-scale lamination (Fig. 8B). This is very similar to what Monty (1976) defined as composite alternating lamination.

\subsection{Quantitative lamination data}

These results show that Leza coarse-grained stromatolites contain the two main stromatolite lamination styles defined by Monty (1976), alternating and repetitive lamination. This off ers an opportunity to further examine and analyze both of them in detail. The original definitions and schematic representations of these lamination styles (see Fig. 1A, D of Monty, 1976) suggest that they are essentially differentiated not only by the microfabrics that form them, but also by the relative thicknesses of their constituent laminae: alternating lamination is formed by consecutive laminae of different microfabric with variable, but overall similar, thickness; and repetitive lamination is formed by laminae of similar microfabric and similar thickness separated by much thinner discontinuity horizons. This suggests that both these lamination styles could be quantitatively distinguished by measuring the relative thicknesses of their laminae.

To test this hypothesis we conducted a metrical analysis of these lamination styles in Leza coarse-grained stromatolites following previous quantitative analyses of relative lamina-thickness (Komar et al., 1965; Bertrand-Sarfati, 1972; Walter, 1972; Preiss, 1973), which compared thicknesses of dark (D) and light (L) laminae using a ' $D / L$ ratio' However, since colour variation in the laminae of Leza coarse-grained stromatolites is more complex than simply dark and light (see Section 4.3, above), we used microfabric rather than colour for metrical analysis: we considered alternating lamination as micrite-rich laminae (M) alternating with grain-rich laminae (G) (Figs. 5, 8), and repetitive lamination as thin micritic crusts $\left(\mathrm{M}^{\prime}\right)$ separating contiguous laminae of the same, typically grain-rich $\left(G^{\prime}\right)$, microfabric (Fig. 9). Evaporite laminae were not measured because they are rare, and therefore not a characteristic constituent of Leza coarse-grained stromatolites lamination.

For this analysis we used 14 thin-sections of Leza coarse-grained stromatolites, and selected areas of the thin-sections which clearly displayed one of the two lamination styles. In each selected area, we measured, under the microscope, 6-10 thickness values of its constituent laminae (i.e., $\mathrm{M}, \mathrm{G}, \mathrm{M}^{\prime}$ or $\mathrm{G}^{\prime}$ ). A mean value was obtained from all measured laminae of the same lamina-type in each selected area (i.e., $\mathrm{M}_{\text {mean }}$, and $\mathrm{G}_{\text {mean }}$, for areas with alternating lamination, and $\mathrm{M}^{\prime}$ mean and $\mathrm{G}_{\text {mean }}^{\prime}$ for areas with repetitive lamination). The relative thickness data for each area were summarised using $M_{\text {mean }} / G_{\text {mean }}$ or $\mathrm{M}_{\text {mean }}^{\prime} / \mathrm{G}_{\text {mean }}^{\prime}$ values. These data show that areas dominated by alternating lamination have $\mathrm{M}_{\text {mean }} / \mathrm{G}_{\text {mean }}$ values in the range of $0.71-2.26$ (mean $=1.35)$, and areas with repetitive lamination have $\mathrm{M}^{\prime}$ mean $/ \mathrm{G}_{\text {mean }}^{\prime}$ values in the range of $0.04-0.32$ (mean $=0.13$ ). For visual comparison, these relative thickness data were plotted in diagrams (Fig. 13), in which each line joins the maximum and minimum values of the lamina-thicknesses from a measured area of a thin section, and thus, each line shows the full thickness range of each measured area of the thin-sections. In these diagrams we recorded the minimum thickness as zero in the common situation of areas where laminae thin and disappear laterally.

To further investigate our quantitative thiclness data, we statistically examined thickness-values of all the measured laminae $(n=192)$, irrespective of their microfabric and of whether they formed alternating or repetitive lamination. These values range from 0 to $3250 \mu \mathrm{m}$, with small values being predominant, producing a right-skewed histogram (Fig. 14A). To obtain a symmetric distribution, we transformed these data, applying natural logarithms (Fig. 14B). The resulting histogram of transformed data suggests a bimodal distribution produced by mixture of two, apparently normal, distributions (Fig. 14B). A modelbased clustering method is required to characterise both distributions and to test their normality. Using the 'mclust' tool for R software 

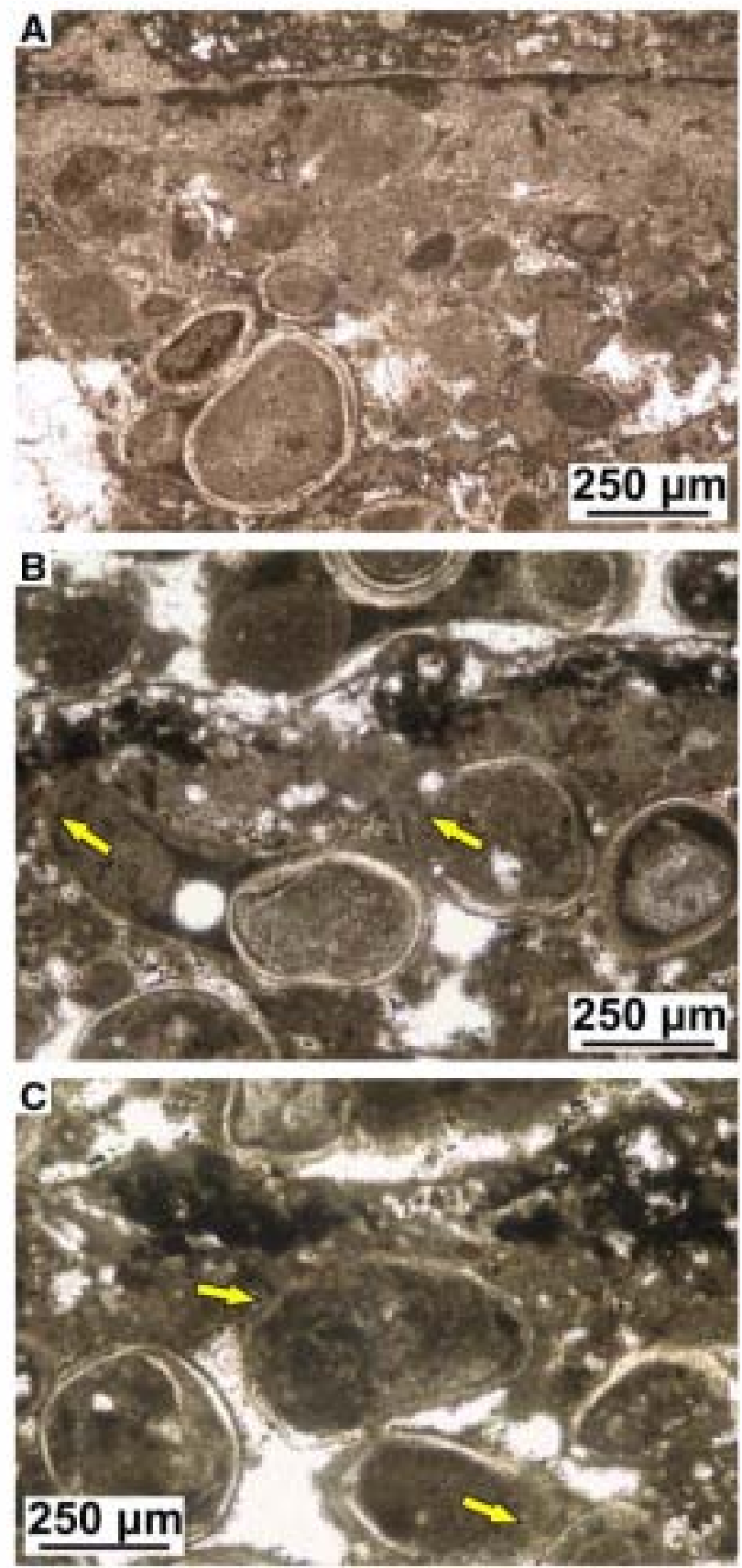

Fig. 11. Micritisation in thin micritic crusts. A: Relatively well-developed thin micritic crust. Grains below the crust surface have diffuse boundaries due to intense micritisation and grain fusion. Note a vertical trend from strongly micritised grains in the upper part, to partially micritised grains in the middle part, and very little micritisation in the lower part. Arnedillo section. B and C: Iess developed thin micritic crusts, in which grains immediately below the crust surface are only partially micritised (arrows). Préjano section.

(Fraley et al., 2012), we obtained a mixture model of two normal populations with their characteristic mean, variance and mixing proportion (Fig. 14B): the first population represents $41 \%$ of the data, and the second population represents $59 \%$. This model also calculated the probability of each datum of belonging to each population. With a probability higher than 0.7 , laminae with thicknesses $<450 \mu \mathrm{m}$ belong to the first population, and those with thiclnesses $>600 \mu \mathrm{m}$ belong to the second population. Iaminae with thicknesses ranging 450-600 $\mu \mathrm{m}$ have similar probabilities of belonging to both populations and can therefore be regarded as the intersection area of both populations (Fig. 14B).

\section{Discussion}

\subsection{Micro fabric interpretation}

The variety of microfabric components in laminae of Leza coarsegrained stromatolites implies that diverse processes were involved in their accretion, lithification, and the origin of their lamination styles.

\subsubsection{Grain-rich laminae}

Sand-size carbonate grains are very common, forming grainy laminae and grain-dominated mixed laminae (Figs. 5-11), in both horizontal and inclined (up to $90^{\circ}$ ) portions of the stromatolite domes. They have the same composition as the grains in the surrounding ooid grainstone facies, but overall are consistently finer. This diff erence in grain-size has been noted in present-day marine coarse-grained carbonate stromatolites formed by stabilisation (trapping and binding) of previously mobile grains by microbial mats (Logan, 1961; Monty, 1976; Dravis, 1983; Reid and Browne, 1991; Riding et al., 1991a; Reid et al., 1999). In these examples, grain-trapping is produced by erect filaments, mat irregularities, and extracellular polymeric substances (EPS) secreted by cyanobacteria and other mat microbes (Logan, 1961; Playford and Cockbain, 1976; Dravis, 1983; Dill et al., 1986; Awramik and Riding, 1988; Riding et al., 1991a; Visscher et al., 1998; Reid et al., 2000; Decho et al., 2005; Dupraz et al., 2009; Browne, 2011; Bowlin et al., 2012; Jahnert and Collins, 2012). Rare filaments in some mixed laminae of the Leza coarse-grained stromatolites (Fig. 7B, C) may be relicts of cyanobacteria. Calcified filaments, similarly preserved, also occur rarely in present-day Bahamian examples (Dravis, 1983; Reid and Browne, 1991; Reid et al., 1995; Macintyre et al., 1996; Feldmann and McKenzie, 1998; Planavsky et al., 2009), and as filament molds at Shark Bay (Reid et al., 2003).

We infer that grain-rich laminae of Leza coarse-grained stromatolites formed in a similar manner to those in Bahamian and Shark Bay examples. The Leza coarse-grained stromatolite palaeoenvironment may have had regular currents (e.g. tides, waves, and/or storms, SuarezGonzalez et al., in press) that continuously supplied grains (preferentially the finer fraction) to the tops and flanks of the stromatolite domes.

\subsubsection{Micrite-rich laminae}

Microfabrics mainly composed of clotted micrite and clottedpeloidal micrite are also common in Leza coarse-grained stromatolites (Figs. 5-9). Both clotted and clotted-peloidal microfabrics are common in ancient and modern microbial carbonates, and they are widely attributed to calcification of microbial mats induced by heterotrophic bacteria (Dalrymple, 1965; Chafetz, 1986; Chafetz and Buczynski, 1992; Reitner, 1993; Dupraz et al., 2004; Riding and Tomás, 2006; Heindel et al., 2010; Spadafora et al., 2010). Micritic fabrics similar to these in Leza coarsegrained stromatolites also occur in present-day coarse-grained carbonate stromatolites and thrombolites, generally filling the intergranular space of grain-rich microfabrics but not typically as relatively thick micritic laminae (Reid and Browne, 1991; Reid et al., 1995, 2003; Feldmann, 1997; Feldmann and McKenzie, 1998; Planavsky and Ginsburg, 2009; Planavsky et al., 2009; Browne, 2011; Jahnert and Collins, 2011, 2012), which is the case in Leza coarse-grained stromatolites, where micrite-rich laminae typically altemate with grain-rich laminae and both display similar mm-scale thicknesses. Nonetheless, there are examples of subtidal stromatolites at Shark Bay, which are dominantly micritic with very scarce grains, and are composed of clotted and clotted-peloidal microfabrics similar to those of Leza coarsegrained stromatolites (Reid et al., 2003; Jahnert and Collins, 2011, 2012). Precipitation of clotted and clotted-peloidal micrite in all these present-day examples has been interpreted to be induced, under anaerobic conditions, by heterotrophic microbes (chiefly sulphate-reducing bacteria) which degrade the EPS mainly secreted by the primary producers of the mat (Feldmann, 1997; Feldmann and McKenzie, 1998; Visscher et al., 1998, 2000; Reid et al., 2000; Andres et al., 2006; 


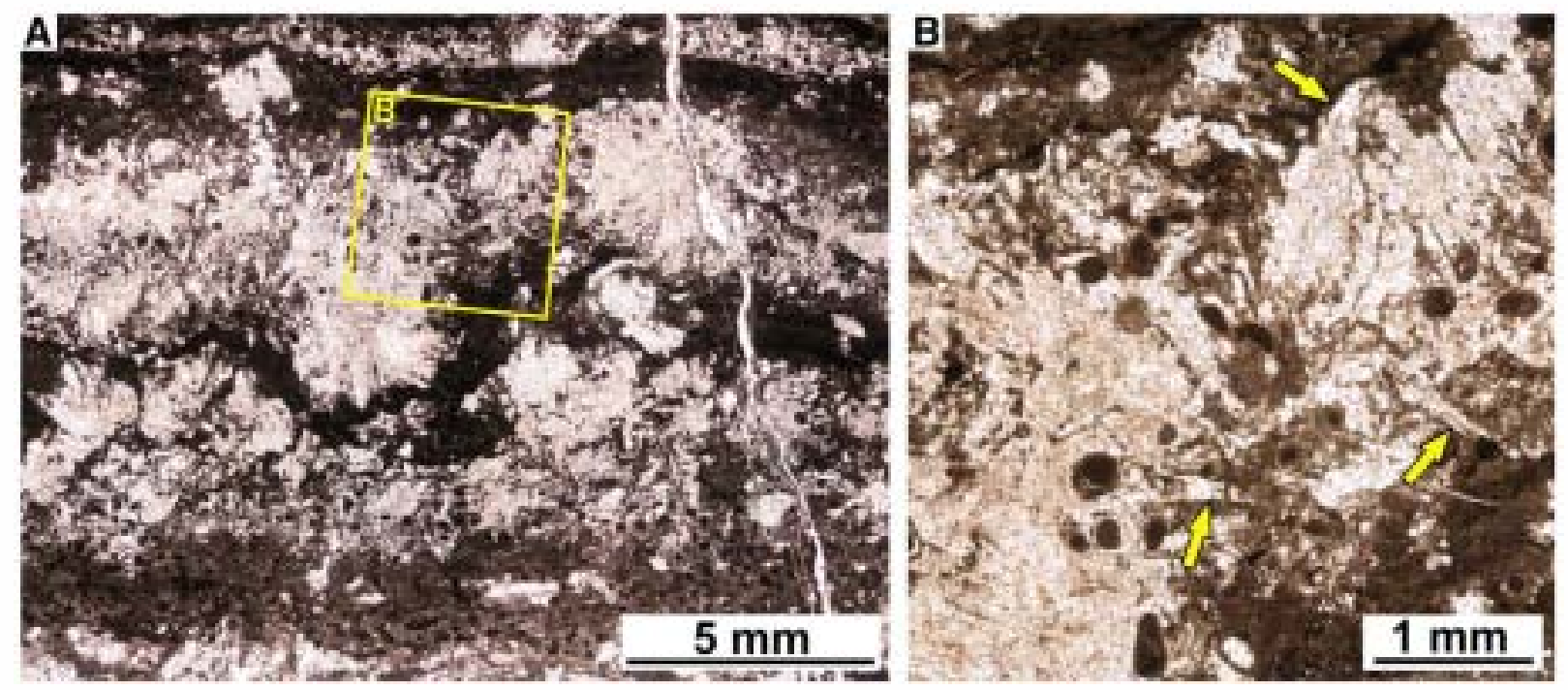

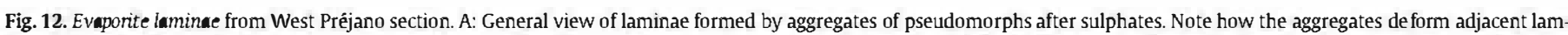

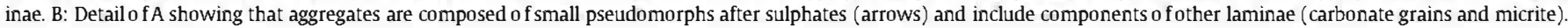

Dupraz et al., 2009; Planavsky and Ginsburg, 2009; Planavsky et al., 2009; Jahnert and Collins, 2012). Therefore, bioinduced precipitation of micrite in these examples can be considered a subsurface process (Feldmann, 1997; Feldmann and McKenzie, 1998) in intergranular spaces of the uppermost millimetres of the microbial mat (Visscher et al., 1998, 2000). Based on comparisons with these and other present-day coarse-grained stromatolites, we infer that micritic laminae formed when the surfaces of Leza coarse-grained stromatolites accreted without significant trapping, and that calcification was primarily achieved by subsequent precipitation of clotted-peloidal and/or clotted micrite, bioinduced by heterotrophs within anaerobic areas of the mat. Micrite-dominated mixed laminae are interpreted to have formed by similar processes, but under circumstances where the surface mat did trap some grains, which were typically concentrated in particular areas of the laminae. Intergranular clotted and clotted-peloidal micrite found in grain-rich laminae is interpreted as similarly bioinduced, but in areas between trapped grains. Laminae of mixed micritic-grainy composition occur in present-day coarse-grained carbonate stromatolites in the Bahamas (Reid and Browne, 1991; Feldmann and Mckenzie, 1998; Planavsky and Ginsburg, 2009) and Shark Bay (Monty, 1976; Reid et al., 2003; Jahnert and Collins, 2011, 2012).

\subsubsection{Thin micritic crusts}

Thin micritic crusts very similar to those in Leza coarse-grained stromatolites have been recognised in present-day coarse-grained carbonate stromatolites. Monty (1976) described thin lithified micritic layers $(\sim 500 \mu \mathrm{m}$ thick), rich in organic matter, separating thicker $(\sim 3 \mathrm{~mm})$ loosely packed unlithified grainy layers, from intertidal Shark Bay stromatolites. He noted that the micrite appears to have been precipitated in situ and is associated with bored and micritised grains. Similar lithified horizons were subsequently described in coarse-grained Bahamian stromatolites from the Exuma Cays (Reid and Browne, 1991; Reid et al., $1995)$ as thin micrite crusts (20-40 $\mu \mathrm{m}$ thick) that generally overlie layers of micritised and truncated grains, 200-1000 $\mu \mathrm{m}$ thick. These crusts are interpreted asformed by biogeochemical processes during hiatuses in stromatolite accretion (Macintyre et al., 1996; Feldmann, 1997; Feldmann and McKenzie, 1998). Visscher et al. (1998, 2000) related formation of these micritic crusts to carbonate precipitationdissolution processes induced by sulphate-reducing bacteria, a few mm below the surface of mats. In a detailed study, Reid et al. (2000) related thin micritic crusts in Bahamian stromatolites to successive mat processes in which Schizothrix mats promoted grain-trapping, heterotrophic bacteria induced precipitation of thin micritic horizons when

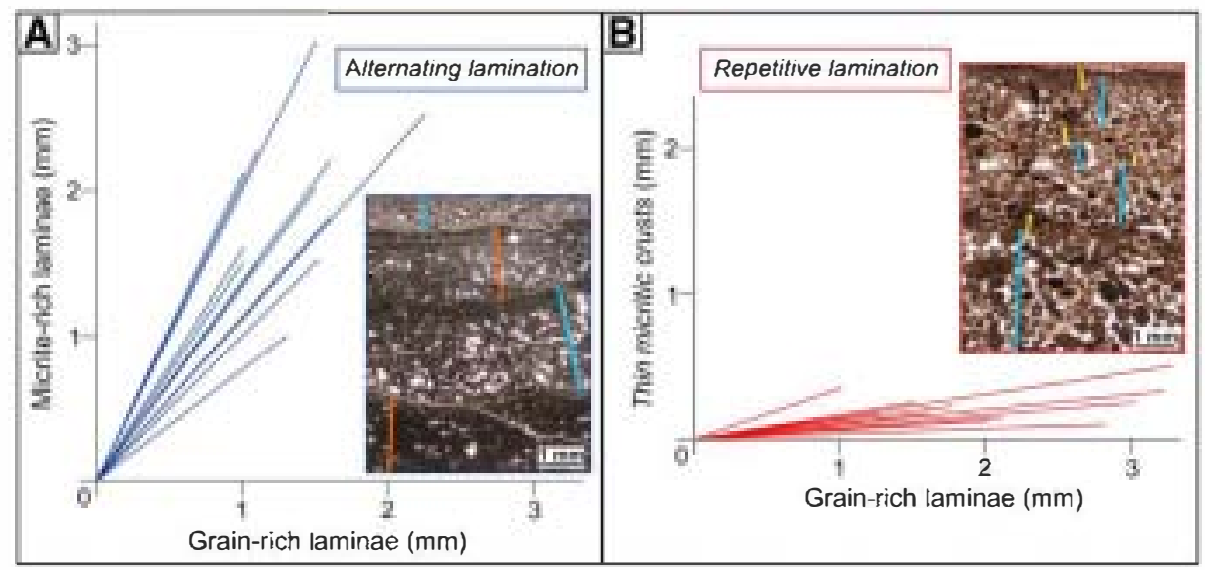

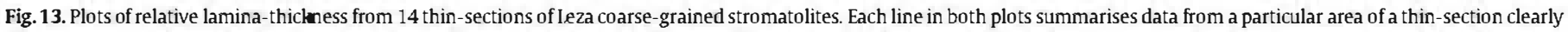

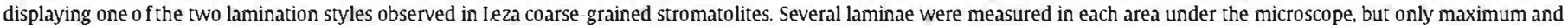

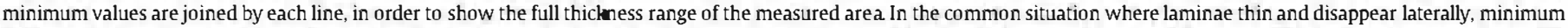

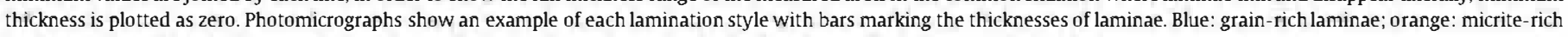
laminae; yellow: thin micritic crust. A: Plot of areas displaying alternating lamination. B: Plot of areas displaying repetitive lamination. 


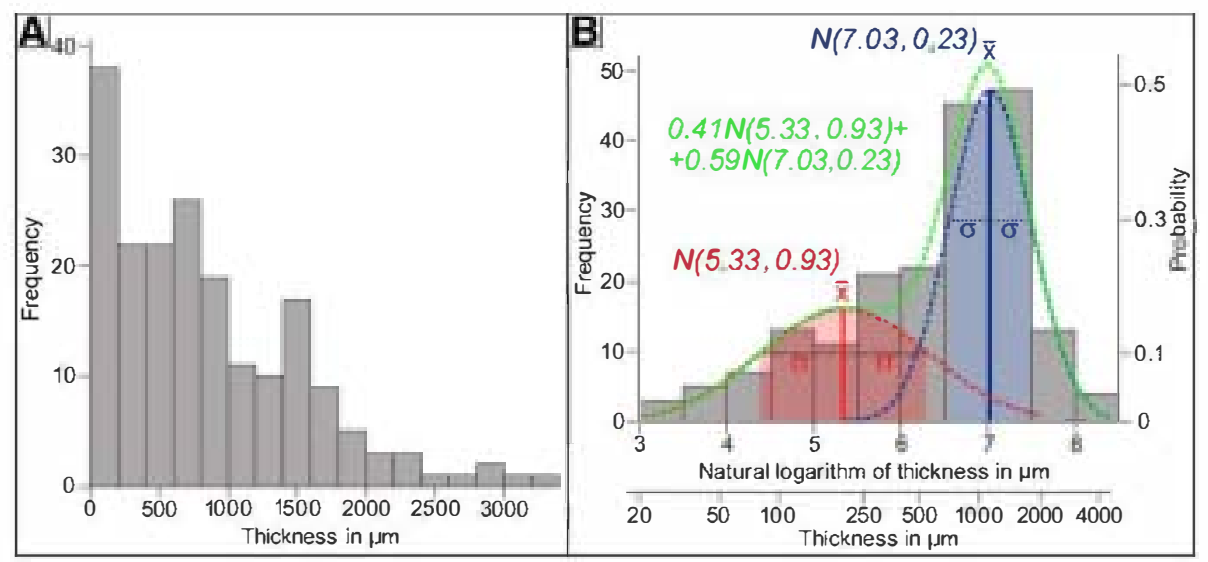

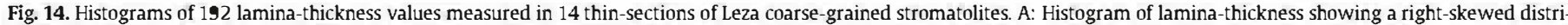

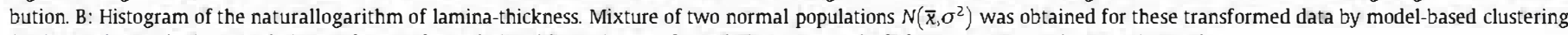
(Fraley et al., 2012). First population: red; second population: blue; mixture of populations: green. Shaded areas represent the $\bar{x} \pm \sigma$ interval.

accretion ceased, and endolithic Solentia cyanobacteria bored and micritised grains during longer hiatal periods (see also Macintyre et al., 2000).

Thin micritic crusts in Leza coarse-grained stromatolites share many of these features, and we infer similar origins for them. Small pyrite crystals observed in the thin micritic crusts of Leza coarse-grained stromatolites (Figs. 7C, 9E) are consistent with an origin related with sulphate-reduction, and resemble the small framboidal pyrite crystals that are by-products of sulphate-reduction in present-day microbial mats (Jørgensen and Cohen, 1977; Visscher et al., 1998; Popa et al., 2004; Jones et al., 2005; Spadafora et al., 2010). Locally, thin micritic crusts show signs of erosion (Fig. 10B), suggesting that significant early lithification of the thin micritic crusts occurred during prolonged hiatal periods.

\subsubsection{Evaporite laminae}

Pseudomorphs after sulphates occur in aggregates that deform the adjacent laminae and include fragments from them (ooids or micrite) (Fig. 12), which suggests that the original minerals grew displacively and replacively, as intrasediment sulphates, once the overlying laminae where already deposited.

Stromatolites are very commonly found interbedded in evaporiterich modern environments and ancient units (e.g., Von der Borch et al., 1977; Pope et al., 2000; Schreiber and El Tabakh, 2000). Stromatolites partially composed of evaporites (typically sulphates) also occur, as products of syndepositional alteration referred to as 'gypsification' (Rouchy and Monty, 1981; Babel, 2007). Additionally, many examples of stromatolites and other microbial carbonates contain displacive and replacive sulphate laminae, similar to those of Leza coarse-grained stromatolites (Gunatilaka, 1975; Horodyski and Vonder Haar, 1975; Park, 1977; Aref, 1998; Gerdes et al., 2000; Rouchy and Monty, 2000; Ortí, 2010). Similarly, we interpret evaporite laminae of the Leza coarse-grained stromatolites as formed by very early diagenetic intrasedimentary precipitation of evaporite minerals when interstitial waters reached oversaturation. The facies association with Leza coarse-grained stromatolites does not typically contain evaporites (see Section 2 above), but it alternates with facies rich in pseudomorphs after sulphates (Fig. 3). This indicates that the tidally-influenced coastal-wetlands that contained Leza coarse-grained stromatolites (Suarez-Gonzalez et al., in press), locally and temporarily became restricted, allowing precipitation of intrasedimentary sulphates within the stromatolites. Similarly, in some areas of Shark Bay, gypsum crystals occur within supratidal microbial mats (Hagan and Logan, 1974; Jahnert and Collins, 2013).

\subsection{Accretion processes and lamination style: origins of lamination}

Just as microfabrics and laminae can be related to process in Leza stromatolite development, their lamination styles reflect the mechanisms by which the stromatolites accreted.

\subsubsection{Macroscopic lamination}

Alternating lamination (sensu Monty, 1976), the predominant macro-lamination in Leza coarse-grained stromatolites (Figs. 4, 5, 8), is formed by alternation of laminae with diff erent microfabric composition, typically grain-rich and micrite-rich laminae (Fig. 8). This reflects alternation of two main accretion processes: grain trapping and binding, and bioinduced calcification. The mixed grainy-micritic composition of many of the stromatolite laminae (Figs. 7, 8, 9) indicates that these two processes were not mutually exclusive, although one was generally predominant. The typically sharp ransition between these alternating laminae (Fig. 8), suggests interruptions in accretion, although gradual transitions are also observed (Fig. 6B), indicating that both accretion processes could progressively grade into each other. In addition, thin micritic crusts occur at lamina contacts (Fig. 8B), and were presumably produced by longer hiatuses in accretion.

Predominance of alternating lamination distinguishes Leza coarsegrained stromatolites from most recent examples of coarse-grained carbonate stromatolites, which generally lack thick micrite-rich laminae (Logan, 1961; Dill et al., 1986; Reid et al., 1995, 2000; Feldmann and McKenzie, 1998). Planavsky and Ginsburg (2009) describe four successive processes responsible for the development of Bahamian microbialites: “1) sediment trapping, binding and initial lithification; 2) disruption and runcation of the initial fabric; 3) pervasive cementation and clot formation; and 4) late-stage boring". Thus, the only accretionary process is trapping and binding of grains and the other processes are very early diagenetic and are related either to alteration of the original fabric or intrasedimentary precipitation. Dupraz et al. (2011) indicate that Bahamian stromatolites are formed by "the iterative growth of different types of microbial mats" and their Fig. 4 shows that the first type of mat is responsible for accretionary graintrapping, the second is involved in precipitation of a thin micritic crust during hiatuses, and the third causes micritisation and fusion of grains below the stromatolite surface. Bowlin et al. (2012) summarise previous studies of Bahamian stromatolite mats and add three more mat types to those described by Dupraz et al. (2011), all of which are involved in trapping and binding of sediment. In Shark Bay stromatolites, Jahnert and Collins (2013) describe six mat types, and Jahnert and Collins (2012) attribute stromatolite development to grain accretion plus four additional cons ructional mechanisms: 1 ) superficial micrite generation 
within organic gel of the mats that stabilises sediment; 2) bioturbation, micritisation and recrystallisation; 3 ) pervasive micrite generation, filling spaces and enveloping grains; and 4) fibrous aragonite precipitation in void spaces. However, in Shark Bay stromatolites, micritic microfabrics do also occur. Reid et al. (2003) interpreted them as calcified mats with little or no trapped and bound sediment, but these are only observed in subtidal grain-poor stromatolites and in the upper parts of some intertidal grainy specimens.

Leza coarse-grained stromatolites therefore differ in detail from these examples of recent coarse-grained carbonate stromatolites in that their macroscopic lamination reflects the altemation of two fabrics, and thus of two accretion processes: grain trapping and calcification of mats that trapped few or no grains. We propose that the development and alternation of these two distinct microfabrics in Leza coarsegrained stromatolites reflects both extrinsic (environmental) and intrinsic (biotic) factors. The Leza Fm was deposited in a system of coastal-wetlands, influenced by both freshwater and seawater, and therefore experienced significant changes in salinity (Suarez-Gonzalez et al., 2013). In addition, facies containing Leza coarse-grained stromatolites were influenced by tides (Suarez-Gonzalez et al., in press) and the presence of evaporite pseudomorphs within the stromatolites indicates that their sedimentary environment underwent changes in salinity. These hydrochemical fluctuations together with the hydrodynamical changes typical of tidal environments could alternately promote grain trapping and mat calcification in Leza coarse-grained stromatolites. However, biotic changes (e.g., altemation of mats of diff ering microbial composition at the stromatolite surface) cannot be ruled out, especially since mats of varied biotic compositions can alternate at the surface of present-day coarse-grained carbonate examples (Bowlin et al., 2012; Jahnert and Collins, 2013).

\subsubsection{Microscopic lamination}

Repetitive lamination (sensu Monty, 1976) is also common in Leza coarse-grained stromatolites, but since it is formed by microscopic thin micritic crusts within laminae of similar microfabric composition (generally grain-rich laminae) it is macroscopically inconspicuous (Figs. 5, 8, 9). Thin micritic crusts of Leza coarse-grained stromatolites are likely to have formed during hiatuses in accretion, as in presentday examples (Macintyre et al., 1996; Feldmann, 1997; Feldmann and McKenzie, 1998; Visscher et al., 1998, 2000; Reid et al., 2000, 2003; Dupraz et al., 2009, 2011). During these interruptions, precipitation of micrite occurs near the stromatolite surface (Visscher et al., 1998, 2000) and, if the hiatus is long enough, micritisation and fusion of subsurface grains also occurs (Macintyre et al., 1996; Reid et al., 2000) (Fig. 11). Following this interpretation, thin micritic crusts in coarsegrained carbonate stromatolites can be considered as essentially hiatal products of alteration and precipitation near the stromatolite surface, rather than as accretionary events (Feldmann, 1997; Feldmann and McKenzie, 1998; see Dupraz et al., 2011, Fig. 4, for a graphical explanation). Evidence of erosion on some previously lithified thin micriticcrusts in Leza coarse-grained stromatolites (Fig. 10B) suggests extended hiatuses in accretion. Erosion of partially lithified stromatolites is also commonly described in present-day coarse-grained examples, due to bioerosion (e.g., Dill et al., 1986), subaerial exposure in supratidal areas (e.g., Jahnert and Collins, 2011), burial and exhumation of the stromatolites by migrating sand waves (Andres and Reid, 2006; Planavsky and Ginsburg, 2009), or physical stress by tidal currents during long periods when no grains were supplied (Feldmann and McKenzie, 1998). In Leza coarse-grained stromatolites, erosion was likely related to subaerial exposure, since stromatolites are laterally and vertically associated with flat pebble breccias formed by micritic intraclasts and stromatolite fragments (Fig. 4C). It is also possible that changes in hydrodynamic conditions (i.e., abnormal tides or storms) were involved in erosion of the stromatolite surface. Resumption of the accretion process occurring prior to the hiatus produced a new lamina, similar in microfabric to the preceding one, creating repetitive lamination.

Repetitive lamination is the dominant lamination style in most present-day examples of coarse-grained carbonate stromatolites (Monty, 1976; Reid and Browne, 1991; Reid et al., 1995, 2000, 2003; Macintyre et al., 1996; Feldmann and McKenzie, 1998; Dupraz et al., $2009,2011)$. Since the thin micritic crusts that define this lamination style are essentially microscopic and often discontinuous and laterally impersistent, the predominance of repetitive lamination in these examples helps explain the irregular and crude macrolamination commonly observed in parts of them (Logan, 1961; Dravis, 1983; Dill et al., 1986; Planavsky and Ginsburg, 2009), that is also reflected in composite descriptive terminologies such as 'thrombolitic stromatolites' (Aitken, 1967), 'thrombolite/stromatolite domes' (Riding et al., 1991a), or 'coarse-grained thrombolites' (Feldmann, 1995).

\subsubsection{Other ancient examples of coarse-grained carbonate stromatolites}

Although present-day coarse-grained carbonate examples are wellknown in the Bahamas and Shark Bay, grainy carbonate laminae are rarely the main components of ancient stromatolites (see Monty, 1977; Awramik and Riding, 1988; Fairchild, 1991; Alternann, 2008; Browne, 2011). Riding et al. (1991b), Arenas and Pomar (2010) and Bourillot et al. (2010) studied examples of coarse-grained carbonate stromatolites of Messinian (late Miocene) age in Spain, and Immenhauser et al. (2005) described Aptian (Early Cretaceous) microbial buildups with crudely-layered coarse-grained carbonate microfabrics in Oman. Other Cretaceous stromatolites from Spain containing some laminae composed of trapped carbonate grains (mainly peloids) have been described (Turonian, Rodriguez-Martínez et al., 2012; Berriasian, Quijada et al., in press). Oxfordian-Kimmeridgian (Upper Jurassic) stromatolites in Poland (Matyszkiewicz et al., 2006, 2012) contain coarse-grained carbonate microfabrics, and Triassic coarse-grained carbonate stromatolites have been described from NE Spain (Mercedes-Martin et al., 2013) and from the SW USA (Woods, 2013). We are not aware of any definite examples of coarse-grained carbonate stromatolites older than Early Triassic.

As in modern examples, ancient coarse-grained stromatolites typically lack thick micrite-rich laminae, and exhibit crude macrolamination mainly defined by thin micritic crusts, similar to those of Leza coarsegrained, Bahamian and Shark-Bay examples (Immenhauser et al., 2005; Matyszkiewicz et al., 2006, 2012; Arenas and Pomar, 2010; Mercedes-Martín et al., 2013). Arenas and Pomar (2010) provide a detailed description of thin micritic laminae in upper Miocene ( 7 M.y.) 'undulate oolitic microbial laminites'. The predominant style of these scarce fossil examples is therefore repetitive lamination. To our knowledge, the thin micritic crusts of Leza coarse-grained stromatolites are the oldest $(\sim 125$ M.y.) well-documented analogues of those in present-day coarse-grained carbonate stromatolites.

\subsubsection{Significance of Leza coarse-grained stromatolites lamination}

Leza coarse-grained stromatolites differ from most published examples of coarse-grained carbonate stromatolites in that they clearly contain both alternating and repetitive lamination, the two main styles defined by Monty (1976). Thin micritic crusts create repetitive lamination but they can also be present at contacts between laminae of differing microfabric in alternating lamination. This demonstrates that hiatuses occurred throughout the development of Leza coarse-grained stromatolites, but they only produced noticeable lamination when they repeatedly interrupted accretion by the same process. When hiatuses occurred between periods of accretion by different processes, macroscopic lamination largely reflects this difference in accretion mechanism, not the hiatus itself. Nonetheless, Leza coarse-grained stromatolites do show that interruptions in accretion can be an additional source of microscopic lamination in stromatolites, although it is readily overshadowed by more conspicuous alternating lamination. However, modern coarsegrained carbonate stromatolites (Monty, 1976; Reid and Browne, 
1991; Reid et al., 1995, 2000, 2003; Macintyre et al., 1996; Feldmann and McKenzie, 1998), as well as some parts of Leza coarse-grained stromatolites (Figs. 5A, 9A), show that if only one accretion process predominates and it is periodically interrupted, then repetitive lamination becomes the main lamination style, and is typically relatively indistinct.

\subsection{Quantitative analysis of lamination}

The methodologies presented here show that differences in lamination can be quantified and compared using a metric analysis of lamina thickness. Analysis of transformed thickness data (Fig. 14B) reveals two different populations, and the intersection between both populations (in the range of 450 to $600 \mu \mathrm{m}$ ) is approximately the upper limit of the thickness range of thin micritic crusts in Leza coarse-grained stromatolites $(\sim 500 \mu \mathrm{m})$. This suggests that the presence of a dist lower population (values $<450 \mu \mathrm{m}$ ) among the lamina thickness data broadly reflects the abundance of thin micritic crusts in Leza coarse-grained stromatolites. Therefore, graphical data analysis by histograms provides useful information that can assist process interpretation; for example, abundant thin micritic crusts could reflect the importance of hiatuses during stromatolite development.

Furthermore, analyses of the relative thicknesses of constituent laminae in both alternating and repetitive lamination (Section 4.4 and Fig. 13) indicate that stromatolite lamination style can be quantitavely assessed. Micrite-rich and grain-rich laminae in alternating lamination are similar in thickness (mean $M / G=1.35$ ) with grain-rich laminae being typically slightly thinner. In contrast, repetitive lamination is formed by thin micritic crusts that are much thinner than the adjacent, typically grain-rich, laminae $\left(\mathrm{M}^{\prime} / \mathrm{G}^{\prime}=0.13\right)$. These data suggest a systematic relationship between relative thickness values and the lamination styles that were defined by Monty (1976).

To further examine this relationship, the same methodology has been applied to published examples of present-day and ancient coarse-grained stromatolites, which typically show repetitive lamination (Monty, 1976; Reid and Browne, 1991; Reid et al., 1995, 2000, 2003; Feldmann and McKenzie, 1998; Matyszkiewicz et al., 2006; Arenas and Pomar, 2010). From these, we selected 13 thin-section images with measurable laminae. In each photomicrograph, maximum and minimum thicknesses of its constituent laminae (grain-rich laminae and thin micritic crusts) were measured to show the full thickness range of each example (Table 1). As in Leza coarse-grained stromatolites, we recorded minimum thickness as zero where laminae thinned and disappeared laterally. Our analysis assumes that the measured images were from sections of the stromatolites cut essentially parallel to growth direction, as is usual in stromatolite studies. The values we obtained should therefore reflect actual lamina thickness. Nonetheless, our lamination analyses are based on the proportional thicknesses of thin micritic crusts $\left(\mathrm{M}^{\prime}\right)$ relative to grain-rich laminae $\left(\mathrm{G}^{\prime}\right)$ that constitute the lamination in these examples. Thus, these relative values should not be significantly affected by oblique cutting of the samples, since the thicknesses of all laminae will be similarly affected by the angle of the cut. Data from published examples are plotted in the same way as for Leza coarse-grained stromatolites (Fig. 15). Their $\mathrm{M}^{\prime} / \mathrm{G}^{\prime}$ values range from 0.02 to 0.5 (mean $=0.16$ ). The similarity between these thickness data (Fig. 15) and those measured in areas of Leza coarse-grained stromatolites with repetitive lamination (Fig. 13) supports the view that most coarse-grained carbonate stromatolites typically show repetitive lamination defined by thin micritic crusts that interrupt the accretion of much thicker laminae, mainly formed by trapped carbonate grains.

Therefore, the quantitative approach presented here suggests a systematic relationship between relative lamina-thickness values and lamination styles, with values $\sim 1$ characteristic of alternating lamination and much lower values (typically $<0.3$ ) being characteristic of repetitive lamination. Since lamination style can be directly linked to fundamental accretion mechanism in stromatolites (i.e., periodic interruption of a single accretion process vs. altemation of different accretion processes), the characterisation of lamination styles with this quantitative approach offers a valuable additional tool that may be applied to studies of the origin and significance of lamination in other examples from the wide variety of ages and settings in which stromatolites have formed.

\section{Conclusions}

The Leza Fm contains one of the oldest known and best-preserved examples of coarse-grained carbonate stromatolites. These partially resemble some present-day Bahamian and Shark Bay examples that mainly form by trapping and binding of carbonate grains. However, Leza coarse-grained examples show certain peculiarities which differentiate them from present-day examples, and which have important implications in the interpretation of accretion processes:

- Iaminae of Leza examples show a wider variety of compositions that include grain-rich laminae formed by trapping and binding of particles, micrite-rich laminae formed by microbially-induced precipitation of clotted and clotted-peloidal micrite, and mixed grainy-micritic laminae formed by a combination of these processes. This implies that surface microbial mats of Leza coarse-grained stromatolites could accrete by grain trapping but also by in-situ calcification, trapping few or no grains. In addition, thin micritic crusts developed at the tops of laminae during hiatuses in accretion due to microbially-induced alteration and precipitation of carbonate. Scarce evaporite laminae are relicts of intrasedimentary sulphates.

Table 1

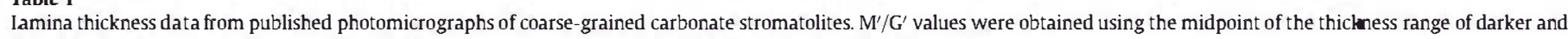
lighter laminae: $\left(\mathrm{M}_{\min }^{\prime}+\left(\mathrm{M}_{\max }^{\prime}-\mathrm{M}_{\min }^{\prime}\right) / 2\right) /\left(\mathrm{G}_{\min }^{\prime}+\left(\mathrm{G}_{\max }^{\prime}-\mathrm{G}_{\min }^{\prime}\right) / 2\right)$. These data are plotted in Fig. 15.

\begin{tabular}{|c|c|c|c|c|c|}
\hline Reference & $\begin{array}{l}\text { Minimum thickness } \\
\text { of thin micritic } \\
\text { crus } \mathbf{-}-\mathrm{M}_{\min }^{\prime}(\mu \mathrm{m})\end{array}$ & $\begin{array}{l}\text { Maximum thickness } \\
\text { thin micritic } \\
\text { crusts- } \mathrm{M}_{\max }^{\prime}(\mu \mathrm{m})\end{array}$ & $\begin{array}{l}\text { Minimum thickness } \\
\text { of grain-rich } \\
\text { laminae- }-G_{\min }^{\prime}(\mu \mathrm{m})\end{array}$ & $\begin{array}{l}\text { Maximum thickness } \\
\text { of grain-rich } \\
\text { laminae- } G_{\text {max }}^{\prime}(\mu \mathrm{m})\end{array}$ & $\mathrm{M}^{\prime} / \mathrm{G}^{\prime}$ \\
\hline Arenas and Pomar (2010), p. 478 Fig. 10e & 19 & 115 & 2308 & 3269 & 0.02 \\
\hline Arenas and Pomar (2010), p. 478 Fig. 10 f & 0 & 114 & 314 & 2571 & 0.04 \\
\hline Arenas and Pomar (2010), p. 478 Fig. $10 \mathrm{~g}$ & 0 & 70 & 330 & 609 & 0.07 \\
\hline Feldmann and McKenzie (1998), p. 206 Fig. 11a & 0 & 500 & 1250 & 3000 & 0.12 \\
\hline Feldmann and McKenzie (1998), p. 206 Fig. 11b & 200 & 550 & 750 & 2800 & 0.21 \\
\hline Matyszkiewicz et al. (2006), p. 258 Fig. 5d & 0 & 381 & 0 & 6190 & 0.06 \\
\hline Monty (1976), p. 214 Fig. 13c & 0 & 667 & 0 & 3333 & 0.20 \\
\hline Reid and Browne (1991), p. 17 Fig. 5a & 0 & 29 & 100 & 714 & 0.04 \\
\hline Reid et al. (1995), p. 17 Plate $7 / 1 \mathrm{~b}$ & 0 & 313 & 213 & 500 & 0.44 \\
\hline Reid et al. (2000), p.991 Fig. 4b & 0 & 938 & 0 & 7188 & 0.13 \\
\hline Reid et al. (2003), p. 307 Plate $46 / 1 \mathrm{c}$ & 80 & 680 & 360 & 1160 & 0.5 \\
\hline Reid et al. (2003), p. 307 Plate $46 / 1 \mathrm{~g}$ & 60 & 200 & 800 & 1040 & 0.14 \\
\hline Reid et al. (2003), p. 309 Plate $47 / 1 \mathrm{~b}$ & 0 & 231 & 0 & 1923 & 0.12 \\
\hline
\end{tabular}




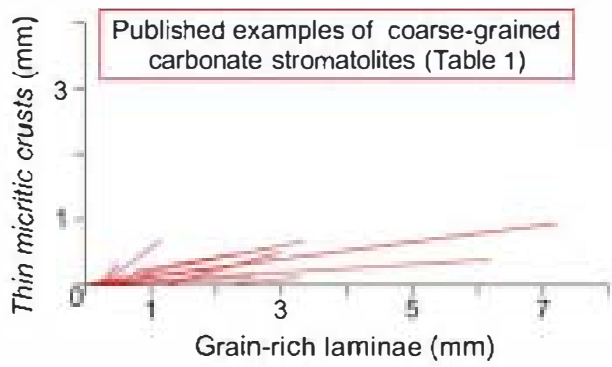

Fig. 15. Plot of thirteen relative lamina-thickness data from eight published studies of present-day and ancient coarse-grained carbonate stromatolites (Table 1). Each line represents one example in which both maximum and minimum thicknesses of the constituent laminae were measured, using the same methodology as in Fig. 13.

- Combinations of these processes created two distinct lamination styles in these stromatolites: macroscopic alternating lamination formed by alternation of laminae of contrasting microfabric (grainrich, micrite-rich), and microscopic repetitive lamination formed by successive laminae of similar microfabric (typically grain-rich laminae) separated by very thin hiatal micritic crusts. Repetitive lamination appears to predominate in most present-day and ancient examples of coarse-grained carbonate stromatolites, but alternating lamination dominates Leza examples, showing that when both lamination styles coexist within the same stromatolite, it is alternating lamination that creates the conspicuous macroscopic lamination.

These differences in accretion process and lamination styles between the Leza and other coarse-grained carbonate stromatolites are likely to be produced by differing environmental conditions, since most other examples of coarse-grained carbonate stromatolites are known from marine environments, whereas Leza examples formed in tide-influenced coastal-wetlands in the varying presence of both seawater and freshwater. This sedimentary environment provided hydrodynamic and hydrochemical fluctuations that help to account for the contrasting accretion processes reflected in the lamination.

Numerical analysis of lamination in these Leza examples and in other coarse-grained carbonate stromatolites shows that lamination style can be quantitatively distinguished using the relative thickness of the constituent laminae. Stromatolite lamination is often regarded as a relatively simple alternation of dark and light layers. Our detailed petrographic and numerical study of Leza coarse-grained stromatolites reveals additional complexity that is likely to help rather than hinder interpretation of stromatolite accretion processes.

\section{Acknowledgements}

This study was funded by the Spanish DIGICYT Project CGL201122709 , by the research group "Sedimentary Basin Analysis" UCM-CM 910429 of the Complutense University of Madrid, and by a FPU scholarship from the Spanish Department of Education. We are grateful to Concha Arenas and an anonymous reviewer for detailed and helpful comments on the manuscript. We thankBeatriz Moral, Gilberto Herrero and Juan Carlos Salamanca for thin-section preparation, to Modesto Escudero for help with computing and scanning, and to Laura Donadeo for help with bibliography.

\section{References}

Aitken, J.D., 1967. Classification and environmental significance of cryptalgal limestones and dolomites, with illustrations from the Cambrian and Ordovician of southwestern Alberta. Journal of Sedimentary Petrology 37, 1163-1178.

Allwood, A.C., Walter, M.R., Kamber, B.S., Marshall, C.P., Burch, LW., 2006. Stromatolite reef from the Early Archaean era of Australia. Nature 441, 714-718.

Alonso, A., Mas, J.R., 1993. Control tectónico e influencia del eustatismo en la sedimentación el Cretácico Inferior de la Cuenca de Los Cameros. España. Cuadernos de Geologia Iberica 17, 285-310.
Altermann, W., 2008. Accretion, trapping and binding of sediment in Archean stromatolites-morphological expression of the antiquity of life. Space Science Reviews $135,55-79$

Andres, M.S., Reid, R.P., 2006. Growth morphologies of modern marine stromatolites: a case study from Highborne Cay, Bahamas. Sedimentary Geology 185, 319-328.

Andres, M.S., Sumner, D.Y., Reid, R.P., Swart, P.K., 2006. Isotopic fingerprints of microbial respiration in aragonite from Bahamian stromatolites. Geology 34, 973-976.

Aref, M.A.M., 1998. Holocene stromatolites and microbial laminites associated with lenticular gypsum in a marine-dominated environment, Ras El Shetan area, Gulf of Aqaba, Egypt. Sedimentology 45, 245-262.

Arenas, C., Pomar, L, 2010. Microbial deposits in upper Miocene carbonates, Mallorca, Spain. Palaeogeography, Palaeoclimatology, Palaeoecology 297, 465-485.

Awramik, S.M., Riding, R, 1988. Role of algal eukaryotes in subtidal columnar stromatolite formation. Proceedings of the National Academy of Sciences of the United States of America 85, 1327-1329.

Babel, M., 2007. Despositional environments of a salina-type evaporite basin recorded in the Badenian gypsum facies in the northern Carpathian Foredeep. In: Schreiber, B.C., Lugli, S., Babel, M. (Eds.), Evaporites Through Space and Time. Geological Society, Iondon, Special Publications, 285, pp. 107-142.

Batchelor, M.T., Burne, R.V., Henry, B.L, Watt, S.D., 2000. Deterministic KPZ model for stromatolite laminae. Physica A 282, 123-136.

Bertrand-Sarfati,J., 1972. Sromatolites columnaires du Précambrien supérieur du Sahara Nord-Occidental. Centre de Recherches sur les Zones Arides, Géologie, 14. CNRS, Paris.

Black, M., 1933. The algal sedimentation of Andros Island Bahamas. Philosophical Trans actions of the Royal Society of Iondon. Series B, Biological Sciences 222, 165-192.

Bourillot, R., Vennin, E., Rouchy, J.M., Durlet, C., Rommevaux, V., Kolodka, C., Knap, F. 2010. Structure and evolution of a Messinian mixed carbonate-siliciclastic platform: the role of evaporites (Sorbas Basin, South-east Spain). Sedimentology 57, 477-512.

Bowlin, E.M., Klaus, J.S., Foster, J.S., Andres, M.S., Custals, L., Reid, R.P., 2012. Environmental controls on microbial community cycling in modern marine stromatolites. Sedimentary Geology 263-264, 45-55.

Braga, J.C., Martín, J.M., Riding, R., 1995. Controls on microbial dome fabric development along a carbonate-siliciclastic shelf-basin transect, Miocene, SE Spain. Palios 10, $347-361$.

Browne, K.M., 2011. Modern marine stromatolitic structures: the sediment dilemma In: Tewari, V.C., Seckbach, J. (Eds.), Stromatolites: Interaction of Microbes with Sediments. Springer, New York, pp. 291-312.

Carozzi, A., 1957. Contribution à I'étude des proprieties géométriques des oolithesL'Exemple du Grand Iac Salé, Utah, USA. Bulletin de l'Institut National Genevois 58, $1-52$.

Chafetz, H.S., 1986. Marine peloids; a product of bacterially induced precipitation of calcite. Journal of Sedimentary Petrology 56, 812-817

Chafetz, H.S., Buczynski, C., 1992. Bacterially induced lithification of microbial mats. Palaios 7, 277-293.

Cloud, P.E., 1942. Notes on stromatolites. American Journal of Science 240, 363-379.

Dalrymple, D.W., 1965. Calcium carbonate deposition associated with blue-green algal mats, Baffin Bay, Texas. Institute of Marine Science Publication 10, 187-200.

Decho, A.W., Visscher, P.T., Reid, P.T., 2005. Production and cycling of natural microbial exopolymers (EPS) within a marine stromatolite. Palaeogeography, Palaeoclimatology, Palaeoecology 219, 71-86.

Dickson, J.A.D., 1966. Carbonate identification and genesis as revealed by staining. Journal of Sedimentary Petrology 36, 491-505.

Dill, RF., Shinn, E.A., Jones, A.T., Kelly, K., Steinen, R.P., 1986. Giant subtidal stromatolites forming in normal salinity waters. Nature $324,55-58$.

Doemel, W.N., Brock, T.D., 1974. Bacterial stromatolites: origin of laminations. Science $184,1083-1085$

Dravis, J.L., 1983. Hardened subtidal stromatolites, Bahamas. Science 219, 385-386.

Dupraz, C., Visscher, P.T., Baumgartner, L.K., Reid, R.P., 2004. Microbe-mineral interactions: early carbonate precipitation in a hypersaline lake (Eleuthera Island, Bahamas). Sedimentology 51, 745-765.

Dupraz, C., Pattisina, R., Verrecchia, E.P., 2006. Translation of energy into morphology: simulation of stromatolite morphospace using a stochastic model Sedimentary Geology 185, 185-203.

Dupraz, C., Reid, RP., Braissant, O., Decho, A.W., Norman, RS., Visscher, P.T., 2009 Processes of carbonate precipitation in modern microbial mats. Earth-Science Reviews 96, 141-162.

Dupraz, C., Reid, P.R, Visscher, P.T., 2011. Modern microbialites. In: Reitner,J., Thiel, V. (Eds.), Encyclopedia of Geobiology. Springer, Dordrecht, pp. 617-635.

Fairchild, I.J., 1991. Origins of carbonate in Neoproterozoic stromatolites and the identifcation of modern analogues. Precambrian Research 53, 281-299.

Feldmann, M., 1995. Controls on stromatolite formation: a comparative study of modern stromatolites from the Bahamas with Messinian examples from southeast Spain Ph.D. Thesis ETH, Zürich, Switzerland

Feldmann, M., 1997. Stromatolitic laminae formation and carbonate precipitation associated with microbial mats from modern Bahamian environments. In: Neuweiler, $F$ Reitner, J., Monty, C. (Eds.), Biosedimentology of microbial buildups. Facies, 36 pp. 200-203.

Feldmann, M., McKenzie, J.A., 1998. Stromatolite-Thrombolite associations in a modern environment: Lee Stocking Island, Bahamas. Palaios 13, 201-212.

Fraley, C., Raftery, A.E., Murphy, T.B., Scrucca, L, 2012. mclust Version 4 for R: normal mixture modelling for model-based clustering, classification, and density estimation Technical Report 597. Department of Statistics, University of Washington. Online: www.stat.washington.edu/research/reports/2012/tr597.pdf.

Gerdes, G., Krumbein, W.E., Noffke, N., 2000. Evaporite microbial sediments. In: Riding, R, Awramik, S.M. (Eds.), Microbial Sediments. Springer, Berlin, pp. 196-208. 
Ginsburg, R.N., Lowenstam, HA., 1958. The influence of marine bottom communities on the depositional environment of sediments. Journal of Geology 66, 310-318.

Golubic, S., 1991. Modem stromatolites-a review. In: Riding, R. (Ed.), Calcareous Algae and Stromatolites. Springer-Verlag, Berlin, pp. 541-561.

Golubic, S., Hofmann, H.J., 1976. Comparison of Holocene and Mid-Precambrian Entophysalidaceae (Cyanophyta) in stromatolitic algal mats: cell division and degradation. Joumal of Paleontology 50, 1074-1082.

Grey, K., 1989. Handbook for the study of stromatolites and associated structures (second draft). In: Kennard, J.M., Burne, RV. (Eds.), Stromatolite Newsletter 14. Bureau of Mineral Resources, Geology and Geophysics, Canberra, Australia, pp. 82-171.

Grotzinger, J.P., Knoll, A.H., 1999. Stromatolites in Precambrian carbonates: evolutionary mileposts or environmental dipsticks? Annual Review of Earth and Planetary Sciences 27, 313-358

Gunatilaka, A., 1975. Some aspects of the biology and sedimentology of laminated algal mats from Mannar lagoon, Northwest Ceylon. Sedimentary Geology 14, 275-300.

Hagan, G.M., Iogan, B.W., 1974. Development of carbonate banks and hypersaline basins, Shark Bay, Western Australia AAPG Memoir 22, 61-139.

Heindel, K., Birgel, D., Peckmann, J., Kuhnert, H., Westphal, H., 2010. Formation of deglacial microbialites in coral reefs off Tahiti (IODP 310) involving sulfate-reducing bacteria. Palains 25, 618-635.

Hofmann, H.J., 1969. Attributes of stromatolites. Geological Survey of Canada paper 69 39.

Hofmann, H.J., 1973. Stromatolites: characteristics and utility. Earth-Science Reviews 9 , 339-373.

Hof mann, H.J., 1977. On Aphebian stromatolites and Riphean stromatolite stratigraphy. Precambrian Research 5, 175-205.

Hof mann, H.J., Grey, K., Hickman, A.H., Thorpe, R.I., 1999. Origin of 3.45 Ga coniform stromatolites in Warrawoona Group, Western Australia. Geological Society of America Bulletin 111, 1256-1262.

Horodyski, R.J., Vonder Haar, S.P., 1975. Recent calcareous stromatolites from Laguna Mormona (Baja California) Mexico. Journal of Sedimentary Petrology 45, 894-906.

Immenhauser, A., Hillgärtner, H., Van Bentum, E., 2005. Microbial-foraminiferal episodes in the Early Aptian of the southern Tethyan margin: ecological significance and possible relation to oceanic anoxic event 1a. Sedimentology 52,77-99.

Jahnert, R.J., Collins, L.B., 2011. Significance of subtidal microbial deposits in Shark Bay, Australia Marine Geology 286, 106-111

Jahnert, R.J., Collins, L.B., 2012. Characteristics, distribution and morphogenesis of subtidal microbial systems in Shark Bay, Australia. Marine Geology 303-306, 115-136.

Jahnert, R.J., Collins, L.B., 2013. Controls on microbial activity and tidal flat evolution in Shark Bay, Western Australia Sedimentology 60 (4), 1071-1099.

Javor, B.J., Castenholz, R.W., 1981. Laminated microbial mats, Laguna Guerrero Negro, Mexico. Geomicrobiology Journal 2, 237-273.

Jones, C.B., 1981. Periodicities in stromatolite lamination from the early Proterozoic Hearne Formation, Great Slave Iake, Canada. Palaeontology 24, 231-250.

Jones, B., Renaut, R.W., Konhauser, K.O., 2005. Genesis of large siliceous stromatolites at Frying Pan Lake, Waimangu geothermal field, North Island, New Zealand. Sedimentology 52, 1229-1252

Jorgensen, B.B., Cohen, Y., 1977. Solar Iale (Sinai). 5. The sulfur cycle of the benthic cyanobacterial mats. Limnology and Oceanography 22, 657-666.

Kalkowsky, E., 1908. Oölith und Stromatolith im nord deutschen Buntsandstein. Zeitschrift der Deutschen Geologischen Gesellschaft 60, 68-125.

Komar, V.A., Raaben, M.E., Semikhatov, M.A., 1965. Study method of Conophyton stromatolites and their stratigraphic importance. Doklady Akademii Nauk SSSR 161 , 1165-1168 (In Russian).

Iogan, B.W., 1961. Cryptozoon and associate stromatolite from the recent, Shark Bay, Western Australia. Journal of Geology 69, 517-533.

Macintyre, I.G., Reid, RP., Steneck, R.S., 1996. Growth history of stromatolites in a Holocene fringing reef, Stocking Island, Bahamas. Journal of Sedimentary Research 66, 231-242.

Macintyre, I.G., Prufert-Bebout, L, Reid, RP., 2000. The role of endolithic cyanobacteria in the formation of lithified laminae in Bahamian stromatolites. Sedimentology 47 , 915-921.

Mas, R, Benito, M.I., Arribas, J., Serrano, A, Guimerà, J., Alonso, A, Alonso-Azcárate, J., 2002a. La cuenca de Cameros: desde la extensión finijurásica-eocretácica a la inversión terciaria-implicaciones en la exploración de hidrocarburos. Zubia 14, 9-64

Mas, R., Segura, M., Salas, R., Fregenal-Martinez, M.A.,Sanz,J.L, Garcia, A., Meléndez, M.N. Carenas, B., Garcia-Hidalgo, J., Ortega, F., Gil,J., Martin-Chivelet, J., 2002b. Chapter 12 Cretaceous: the Iberian basin. In: Gibbons, W., Montero, M.T. (Eds.), The Geology of Spain. Geological Society, london, pp. 284-288.

Maslov, V.P., 1960. Stromatolites: their genesis, method of study, relationship to facies, and their geological importance based on examples from the Ordovician of the Siberian Platform. Acadermy of Sciences of the USSR, Geological Institute Proceedings, 41 (In Russian).

Mata, S.A., Harwood, C.L, Corsetti, F.A., Stork, N.J., Eilers, K., Berelson, W.M., Spear, J.R., 2012. Influence of gas production and filament orientation on stromatolite microfabric. Palaios 27, 206-219.

Matyszkewicz, J., Krajewski, M., Kedzierski, J., 2006. Origin and evolution of an Upper Jurassic complex of carbonate buildups from Zegarowe Rocks (Kraków-Wielun Upland, Poland). Facies 52, 249-263.

Matyszkiewicz,J., Kochman, A., Duś, A., 2012. Influence of local sedimentary conditions on development of microbialites in the Oxfordian carbonate buildups from the southern part of the Kraków-Czestochowa Upland (South Poland). Sedimentary Geology 263264, 109-132.

Mercedes-Martin, R., Salas, R., Arenas, C., 2013. Facies heterogeneity and depositional models of a Ladinian (Middle Triassic) microbial-dominated carbonate ramp system (Catalan Coastal Ranges, NE Spain). Marine and Petroleum Geology 46, 107-128.
Monty, C.L.V., 1976. The origin and development of cryptalgal fabrics. In: Walter, M.R (Ed.), Stromatolites. Developments in Sedimentology, 20. Elsevier, Amsterdam, pp. 193-249.

Monty, C., 1977. Evolving concepts on the nature and the ecological significance of stromatolites. In: Flügel, E. (Ed. ), Fossil Algae: Recent Results and Developments. Springer-Verlag, Berlin, pp. 15-35.

Nicholson, J.A.M., Stolz, J.F., Pierson, B.K., 1987. Structure of a microbial mat at Great Sippewissett Marsh, Cape Cod, Massachusetts. FEMS Microbiology Letters 45, $343-364$

Orti, F., 2010. Evaporitas: formaciones marinas y continentals. Algunos ejemplos. In: Arche, A. (Ed.), Sedimentologia. Del proceso fisico a la cuenca sedimentaria. CSIC Madrid, pp. 771-838.

Park, RK., 1976. A note on the significance of lamination in stromatolites. Sedimentology 23, 379-393.

Park, R.K., 1977. The preservation potential of some recent stromatolites. Sedimentology 24, 485-506.

Petryshyn, VA.., Corsetti, F.A., 2011. Analysis of growth directions of columnar stromatoIites from Walker Lake, western Nevada. Geobiology 9, 425-435.

Petryshyn, V.A., Corsetti, F.A., Berelson, W.M., Beaumont, W., Lund, S.P., 2012. Stromatolite lamination frequency, Walker Lake, Nevada: implications for stromatolites as biosignatures. Geology 40, 499-502.

Planavsky, N., Ginsburg, R.N., 2009. Taphonomy of modern marine Bahamian microbialites. Palaios 24, 5-17.

Planavsky, N., Grey, K., 2008. Stromatolite branching in the Neoproterozoic of the Centralian Superbasin, Australia: an investigation into sedimentary and microbial control of stromatolite morphology. Geobiology 6, 33-45.

Planavsky, N., Reid, RP., Lyons, T.W., Myshrall, K.L, Visscher, P.T., 2009. Formation and diagenesi s of modern marine calcified cyanobacteria. Geobiology 7, 566-576.

Playford, P.E., Cockbain, A.E., 1976. Modem algal sromatolites at Hamelin Pool, a hypersaline barred basin in Shark Bay, Western Australia. In: Walter, M.R (Ed.), Sromatolites. Developments in Sedimentology, 20. Elsevier, Amsterdam, pp. 389-411.

Popa, R., Kinkle, B.K., Badescu, A, 2004. Pyrite framboids as biomarkers for iron-sulfur systems. Geomicrobiology Journal 21, 193-206.

Pope, M.C., Grotzinger, J.P., Schreiber, B.C., 2000. Evaporitic subtidal stromatolites produced by insitu precipitation: textures, facies associations, and temporal significance. Journal of Sedimentary Research 70, 1139-1151.

Preiss, W.V., 1973. The systematics of South Australian Precambrian and Cambrian stromatolites. Part II. Transactions of the Royal Society of South Australia 97, 91-125,

Quijada, I.E., Suarez-Gonzalez, P., Benito, M.I., Mas, J.R, Alonso, A., 2010. Un ejemplo de llanura fluvio-deltaica influenciada por las mareas: el yacimiento de icnitas de Serrantes (Grupo Oncala, Berriasiense, Cuencade Cameros, N. de España). Geogaceta 49, 15-18

Quijada, I.E., Suarez-Gonzalez, P., Benito, M.I., Mas, J.R., 2013a. Depositional depth of laminated carbonate deposits: insights from the Lower Cretaceous Valdeprado Formation (Cameros Basin, N Spain). Journal of Sedimentary Research 83, 241-257.

Quijada, I.E., Suarez-Gonzalez, P., Benito, M.I., Mas, J.R., 2013b. New insights on stratigraphy and sedimentology of the Oncala Group (eastern Cameros Basin): implication for the paleogeographic reconstruction of NE Iberia at Berriasian times. Joumal of Iberian Geology 39, 313-334.

Quijada, I.E., Suarez-Gonzalez, P., Benito, M.I., Mas, J.R., 2014. Tidal versus continental sandy-muddy flat deposits: evidence from the Oncala Group (Early Cretaceous, $\mathrm{N}$ Spain). IAS Special Publication, 48 (in press).

R Development Core Team, 2012. R: a language and environment for statistical computing R Foundation for Statistical Computing, Viena (http://wwww.R-project.org/)

Reid, R.., Browne, K.M., 1991. Intertidal stromatolites in a fringing Holocene reef complex, Bahamas. Geology 19, 15-18.

Reid, R.P., Macintyre, I.G., Browne, K.M., Steneck, RS., Miller, T., 1995. Modern marine stromatolites in the Exuma Cays, Bahamas: uncommonly common. Facies 33, 1-18.

Reid, R.P., Macintyre, I.G., Steneck, R.S., 1999. A microbialite/algal ridge fringing reef complex, Highborne Cay, Bahamas. Atoll Research Bulletin 465, 1-18.

Reid, R.P., Visscher, P.T., Decho, A.W., Stolz, J.F., Bebout, B.M., Dupraz, C., Macintyre, I.G. Paerl, H.W., Pinckney, J.L, Prufert-Bebout, L., Steppe, T.F., DesMarais, D.J., 2000. The role of microbes in accretion, lamination and early lithification of modern marine stromatolites. Nature 406, 989-992.

Reid, R.P., James, N.P., Macintyre, I.G., Dupraz, C.P., Burne, RV., 2003. Shark Bay stromatolites: microfabrics and reinterpretation of origins. Fac les 49, 299-324.

Reitner, J., 1993. Modern cryptic microbialite/Metazoan facies from Lizard Island (Great Barrier Reef, Australia). Formation and concepts. Facies 29, 3-40.

Riding. R., 2000. Microbial carbonates: the geological record of calcified bacterial-algal mats and biofilms. Sedimentology 47 (Suppl. 1), 179-214

Riding, R., 2011. Microbialites, stromatolites, and thrombolites. In: Reitner, J., Thiel, V (Eds.), Encyclopedia of Geobiology. Springer, Dordrecht, pp. 635-654.

Riding, R., Tomás, S., 2006. Stromatolite reef crusts, Early Cretaceous, Spain: bacterial origin of in situ-precipitated peloid microspar? Sedimentology 53, 23-34.

Riding, R., Awramik, S.M., Winsborough, B.M., Griffin, K.M., Dill, R.F., 1991a. Bahamian giant stromatolites: microbial composition of surface mats. Geological Magazine $128,227-234$

Riding, R., Braga, J.C., Martin, J.M., 1991b. Oolite stromatolites and thrombolites, Miocene, Spain: analogues of Recent giant Bahamian examples. Sedimentary Geology 71 , $121-127$.

Roddy, H.J., 1915. Concretions in streams formed by the agency of blue-green algae and related plants. Proceedings of the American Philosophical Society 54 , $246-258$

Rodriguez-Martinez, M., Sánchez, F., Walliser, E.O., Reitner, J., 2012. An Upper Turonian fine-grained shallow marine stromatolite bed from the Muñecas Formation. Northern Iberian Ranges, Spain. Sedimentary Geology 263-264, 96-108. 
Rouchy, J.M., Monty, C.L., 1981. Stromatolites and cryptalgal laminites associated with Messinian gypsum of Cyprus. In: Monty, C. (Ed.), Phanerozoic Stromatolites: Case Histories. Springer-Verlag, New York, pp. 155-180.

Rouchy, JM., Monty, C., 2000. Gypsum microbial sediments: Neogen and Modern examples. In: Riding, R., Awram ik, S.M. (Eds.), Microbial Sediments. Springer, Berlin, pp. 209-216.

Schreiber, B.C., El Tabakh, M., 2000. Deposition and early alteration of evaporites Sedimentology 47 (SuppL 1), 215-238.

Schulz, E., 1936. Das Farbstreifen-Sandwatt und seine Fauna, eine ökologische biozönotische Untersuchung an der Nordsee. Kieler Meeresforschungen 1, $359-378$.

Semikhatov, M.A., Raaben, M.E., 2000. Proterozoic stroma tolite taxonomy and biostratigraphy. In: Riding, R., Awramik, S.M. (Eds.), Microbial Sediments. Springer, Berlin, pp. 295-306

Semikhatov, M.A., Gebelein, C.D., Cloud, P., Awramik, S.M., Benmore, W.C., 1979. Stromatolite morphogenesis-progress and problems. Canadian Journal of Earth Sciences 16, 992-1015.

Seong-Joo, L., Browne, K.M., Golubic, S., 2000. On stromatolite lamination. In: Riding, R. Awramik, S.M. (Eds.), Microbial Sediments. Springer, Berlin, pp. 16-24.

Spadafora, A. Perri, E., Mc Kenzie, J.A., Vasconcelos, C., 2010. Microbial biomineralization processes forming modern Ca:Mg carbonate stromatolites. Sedimentology 57, 27-40.

Storrie-I ombardi, M.C., Awramik, S.M.,2006. A sideways view of stroma tolites: comple Xity metrics for stromatolite laminae. In: Hoover, R. B., Levin, G.V., Rozanov, A.Y. (Eds.), Instruments, Methods and Missions for Astrobiology IX. SPIE, San Diego, pp. 1-12.

Suarez-Gonzalez, P., Quijada, LE, Mas, J.R., Benito, M.L, 2010. Nuevas aportaciones sobre la in fluen cia marina y la edad de Ios carbonatos de la Fm Leza en el sector de Préjano (SE de La Rioja). Cretácico Inferior, Cuenca de Cameros. Geogaceta 49, 7-10.

Suarez-Gonzalez, P., Quijada, E., Benito, M.L, Mas, J.R., 2013. Eustatic versus tectonic control in an intraplate rift basin (Leza Fm, Cameros Basin). Chronostratigraphic and paleogeographic implications for the Aptian of Iberia. Journal of Iberian Geology 39, 285-312.

Suarez-Gonzalez, P., Quijada, E., Benito, M.L, Mas, J.R., 2014. Do stromatolites need tides to trap ooids? Insights from a Cretaceous system of coastal-wetlands. IAS Special Publication, 48 (in press).

Takashima, C., Kano, A., 2008. Microbial processes foming daily lamination in a stromatolitic travertine. Sedimentary Geology 208, 114-119.

Visscher, P.T., Reid, R.P., Bebout, B.M., Hoeft, S.E., Macin tyre, LG., Thompson Jr., J.A., 1998. Formation of lithified micritic laminae in modern marine stromatolites (Bahamas): the role of sulfur cycling. American Mineralog ist 83, 1482-1493.

Visscher, P.T., Reid, R.P., Bebout, B.M., 2000. Microscale observations of sulfate reduction: correlation of microbial activity with Iithified micritic laminae in modern marine stromatolites. Geology 28, 919-922.

Vologdin, A.G., 1962. The oldest algae of the USS R. Academy of Sciences of the. USSR, Moscow (In Russian).

Von der Borch, C.C., Bolton, B, Warren, J.K., 1977. Environmental setting and microstructure of subfossil lithified stromatolites associated with evaporites, Marion Iake, South Australia. Sedimento logy 24, 693-708.

Wagstaff, K.L., Corsetti, F.A., 2010. An evaluation of information-theoretic methods for detecting structural microbial biosignatures. Astrobiology 10, 363-379.

Walter, M.R. 1972. Stromatolites and the biostratigraphy of the Australian Pre cambrian and Cambrian. Spe cial Papers in Palaeontology, 11. The Palaeontological Association, I ondon.

Warren, J.K., 2006. Evaporites: sediments. Resources and Hydrocarbons.Springer, Berlin.

Woods, A.D, 2013. Microbial ooids and cortoids from the Lower Triassic (Spathian) Virgin Limestone, Nevada, USA: evidence for an Early Triassic microbial bloom in shallow depositional environments. G Iobal and Planetaty Change 105, 91-101.

Zhang, Y., Jin, L., Xiao, S., Liang, Y., 1993. Image analysis of stromatolite fabric using a spatial frequency power spectrum analysis system. Journal of Geology 101, 591-602. 